\title{
Reconciling drainage and receiving basin signatures of the Godavari River system
}

\author{
Muhammed Ojoshogu Usman ${ }^{1}$, Frédérique Marie Sophie Anne Kirkels ${ }^{2}$, Huub Michel Zwart ${ }^{2}$, Sayak Basu ${ }^{3}$, \\ Camilo Ponton $^{4}$, Thomas Michael Blattmann ${ }^{1}$, Michael Ploetze ${ }^{5}$, Negar Haghipour ${ }^{1,6}$, Cameron McIntyre ${ }^{1,6,7}$, \\ Francien Peterse $^{2}$, Maarten Lupker ${ }^{1}$, Liviu Giosan ${ }^{8}$, and Timothy Ian Eglinton ${ }^{1}$ \\ ${ }^{1}$ Geological Institute, ETH Zürich, Sonneggstrasse 5, 8092 Zürich, Switzerland \\ ${ }^{2}$ Department of Earth Sciences, Utrecht University, Heidelberglaan 2, 3584 CS Utrecht, the Netherlands \\ ${ }^{3}$ Department of Earth Sciences, Indian Institute of Science Education and Research Kolkata, \\ 741246 Mohanpur, West Bengal, India \\ ${ }^{4}$ Division of Geological and Planetary Science, California Institute of Technology, 1200 East California Boulevard, \\ Pasadena, California 91125, USA \\ ${ }^{5}$ Institute for Geotechnical Engineering, ETH Zürich, Stefano-Franscini-Platz 3, 8093 Zürich, Switzerland \\ ${ }^{6}$ Laboratory of Ion Beam Physics, ETH Zürich, Otto-Stern-Weg 5, 8093 Zürich, Switzerland \\ ${ }^{7}$ Scottish Universities Environmental Research Centre AMS Laboratory, Rankine Avenue, East Kilbride, \\ G75 0QF Glasgow, Scotland \\ ${ }^{8}$ Geology and Geophysics Department, Woods Hole Oceanographic Institution, 86 Water Street, \\ Woods Hole, Massachusetts 02543, USA
}

Correspondence: Muhammed Ojoshogu Usman (muhammed.usman@erdw.ethz.ch)

Received: 12 January 2018 - Discussion started: 8 February 2018

Revised: 18 May 2018 - Accepted: 24 May 2018 - Published: 7 June 2018

\begin{abstract}
The modern-day Godavari River transports large amounts of sediment (170 Tg per year) and terrestrial organic carbon $\left(\mathrm{OC}_{\text {terr }} ; 1.5 \mathrm{Tg}\right.$ per year $)$ from peninsular India to the Bay of Bengal. The flux and nature of $\mathrm{OC}_{\text {terr }}$ is considered to have varied in response to past climate and human forcing. In order to delineate the provenance and nature of organic matter (OM) exported by the fluvial system and establish links to sedimentary records accumulating on its adjacent continental margin, the stable and radiogenic isotopic composition of bulk OC, abundance and distribution of long-chain fatty acids (LCFAs), sedimentological properties (e.g. grain size, mineral surface area, etc.) of fluvial (riverbed and riverbank) sediments and soils from the Godavari basin were analysed and these characteristics were compared to those of a sediment core retrieved from the continental slope depocenter. Results show that river sediments from the upper catchment exhibit higher total organic carbon (TOC) contents than those from the lower part of the basin. The general relationship between TOC and sedimentological parameters (i.e. mineral surface area and grain size) of the sediments suggests that
\end{abstract}

sediment mineralogy, largely driven by provenance, plays an important role in the stabilization of OM during transport along the river axis, and in the preservation of OM exported by the Godavari to the Bay of Bengal. The stable carbon isotopic $\left(\delta^{13} \mathrm{C}\right)$ characteristics of river sediments and soils indicate that the upper mainstream and its tributaries drain catchments exhibiting more ${ }^{13} \mathrm{C}$ enriched carbon than the lower stream, resulting from the regional vegetation gradient and/or net balance between the upper ( $\mathrm{C}_{4}$-dominated plants) and lower $\left(\mathrm{C}_{3}\right.$-dominated plants) catchments. The radiocarbon contents of organic carbon $\left(\Delta^{14} C_{O C}\right)$ in deep soils and eroding riverbanks suggests these are likely sources of "old" or pre-aged carbon to the Godavari River that increasingly dominates the late Holocene portion of the offshore sedimentary record. While changes in water flow and sediment transport resulting from recent dam construction have drastically impacted the flux, loci, and composition of OC exported from the modern Godavari basin, complicating reconciliation of modern-day river basin geochemistry with that recorded in continental margin sediments, such investigations provide 
important insights into climatic and anthropogenic controls on OC cycling and burial.

\section{Introduction}

Rivers form a key component of the global carbon cycle, transporting about 200-400 Tg of particulate organic carbon (POC) to the oceans annually (Degens et al., 1991; Ludwig et al., 1996; Schlünz and Schneider, 2000), with the majority of this POC deposited on the continental margins (Berner, 1989; Hedges, 1992). Much of this POC is mobilized from soils (Meybeck, 1982; Tao et al., 2015) and augmented by recently biosynthesized higher plant debris, recycled fossil OC derived from erosion of sedimentary rocks, and in situ aquatic productivity within the rivers (Hedges et al., 1986). Rivers act not only as conduits linking terrestrial and marine reservoirs but also as reactors where terrestrial $\mathrm{OC}\left(\mathrm{OC}_{\text {terr }}\right)$ is subject to a myriad of processes resulting in degradation and modification of the suspended OC load (Aufdenkampe et al., 2011; Wu et al., 2007; Cole et al., 2007). Although a general framework for describing the origin and evolution of $\mathrm{OC}_{\text {terr }}$ in different types of river basins is emerging (e.g. Blair and Aller, 2012), a detailed understanding of the impact of the diverse and complex array of processes occurring within river basins on the amount and composition of $\mathrm{OC}_{\text {terr }}$ that is ultimately exported offshore is still developing.

The flux and nature of OC discharged to the ocean is dependent on a number of factors, including the composition of underlying bedrock, geomorphologic properties, and climatic factors like temperature and precipitation (Hilton et al., 2008; Leithold et al., 2006). Climate variability on millennial and longer timescales is considered to exert an important influence on the export of OC from the terrestrial biosphere and burial in ocean sediments, with important feedbacks on atmospheric $\mathrm{CO}_{2}$. Variations in exhumation, oxidation, and burial of bedrock OC exported from river basins is considered to exert fundamental controls on atmospheric $\mathrm{CO}_{2} / \mathrm{O}_{2}$ balance over longer ( $>$ million year) timescales (Berner, 2003).

Tropical and subtropical rivers are estimated to account for more than $70 \%$ of the global $\mathrm{OC}_{\text {terr }}$ delivery to the oceans (Ludwig et al., 1996; Schlünz and Schneider, 2000) and thus comprise major vectors in land-ocean carbon transport (Aufdenkampe et al., 2011; Galy and Eglinton, 2011; Hedges et al., 1986; Schefuss et al., 2016; Spencer et al., 2012). The discharge of such rivers is sensitive to variations in climate, such as the location and intensity of monsoonal rains and dry-season droughts. Fluvially derived OC, deposited and preserved in adjacent continental margins, serves as a rich archive of information on past perturbations in continental climate and fluvial dynamics (Bendle et al., 2010; Schefuss et al., 2011; Weijers et al., 2007).
The Godavari River basin (Fig. 1) is an example of a monsoon-influenced low-latitude river basin and, as the largest non-Himalayan river in India, is of special interest due to its large catchment size and sediment flux to the ocean (Kale, 2002). Draining central peninsular India, the river integrates rainfall within the core monsoon zone of central India, both reflecting the mean monsoon regime and capturing fluctuations in monsoonal rains over the sub-continent. With over $90 \%$ of discharge from the Godavari deriving from summer monsoon precipitation (Rao et al., 2005), corresponding offshore sedimentary sequences record past variations in continental climate as well as anthropogenic activity within the drainage basin (Cui et al., 2017; Giosan et al., 2017; Ponton et al., 2012; Zorzi et al., 2015).

Prior studies, spanning the Holocene, of a Godavari Riverproximal sediment core NHGP-16A from the Bay of Bengal $(\mathrm{BoB})$ have revealed marked geochemical and sedimentological variations that have been interpreted in the context of both evolving regional hydroclimate and accompanying changes in land use within the Godavari catchment (Giosan et al., 2017; Ponton et al., 2012). Specifically, a distinct change in the stable carbon isotopic $\left(\delta^{13} \mathrm{C}\right)$ composition of molecular markers of terrestrial vegetation implies an increase in the proportion of aridity-adapted $\mathrm{C}_{4}$ vegetation beginning around $4.5 \mathrm{kyr} \mathrm{BP}$ (Ponton et al., 2012). This shift in vegetation type is accompanied by increased variability in the oxygen isotopic composition of planktonic foraminiferal carbonate, suggesting enhanced hydrological variability, potentially reflecting less frequent ("break monsoon") but intense rainfall activity within the drainage basin (Ponton et al., 2012). Subsequent down-core geochemical and sedimentological measurements on the Godavari-proximal BoB sediments have served to paint a more comprehensive picture of past changes within the Godavari basin (Giosan et al., 2017). Notably, sharp increases in sediment accumulation rate during the late Holocene imply a concomitant increase in fluvial sediment discharge, despite the onset of increasingly arid conditions. Furthermore, detrital Neodymium $(\mathrm{Nd})$ isotopic compositions indicate a shift in sediment provenance at ca. 4.5 kyr BP from a relatively unradiogenic signature consistent with lower-basin bedrock as the primary detrital mineral sources prior to increased contributions from the more radiogenic rocks in the upper basin (Deccan Plateau). Finally, these changes recorded in the sediment core are also associated with increased ${ }^{14} \mathrm{C}$ age offsets between bulk OC and coeval planktonic foraminifera, suggesting enhanced erosion and export of pre-aged $\mathrm{OC}_{\text {terr }}$ exhumed from deeper soil layers (Giosan et al., 2017). Collectively, these different lines of evidence are consistent with an overall scenario in which increasing aridity results in a shift in the type (from deciduous to shrub or grass) and extent (reduced) of vegetation coverage, while changes in the pattern and frequency of seasonal monsoons promote enhanced soil erosion in the driest regions of the upper basin. Increased soil loss may have been exacerbated by human activity through intensification 


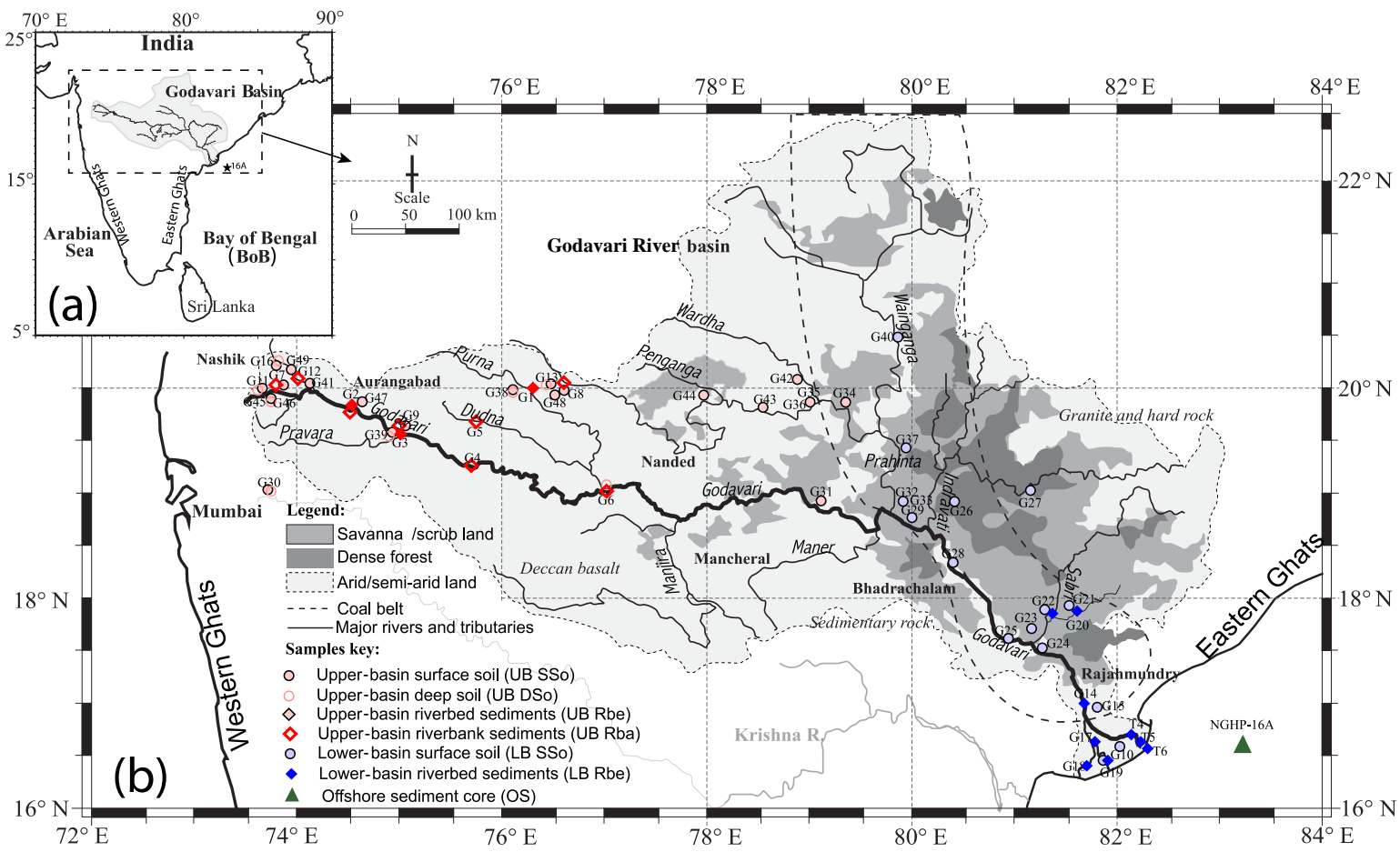

(c)
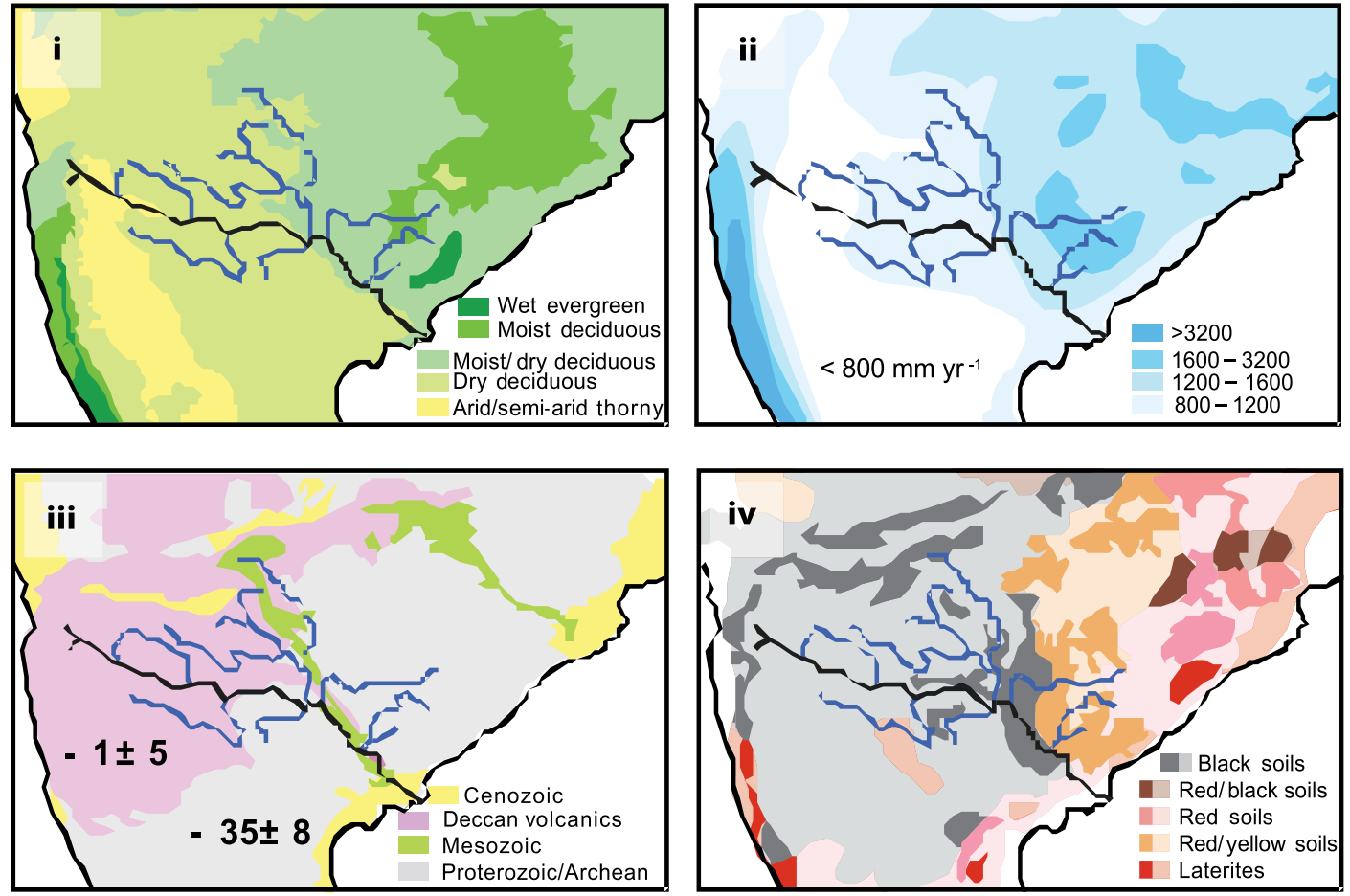

Figure 1. (a) Location of the Godavari River basin in central peninsular India. (b) Sampling locations along the river basin. Upper- (UB) and lower-basin (LB) samples are shown in red and blue colours, respectively (Modified from Pradhan et al., 2014). (c) The Godavari drainage basin in its ecological (i), hydroclimatic (ii), geological (iii), and soil cover (iv) context (Modified from Giosan et al., 2017). 
of agriculture and the implementation of irrigation practices that amplify soil disturbance and destabilization (Giosan et al., 2017).

Although the above interpretations appear to be consistent with available geochemical observations, support is lacking from direct observations on spatial variations in geochemical, mineralogical, and sedimentological properties within the Godavari drainage basin. Furthermore, direct attribution of signatures observed in the sediment record with those of the drainage basin remains elusive. In the present study, we assess the extent to which terrestrial signatures recorded in river-proximal continental margin sediments can be reconciled with those within (specific regions of) the river basin. In particular, we seek to establish whether OC characteristics of the basin are consistent with those of distal sediments deposited during the Holocene on the adjacent continental margin. In addition to bulk and molecular characteristics of particulate organic matter, we explore quantitative and compositional relationships to mineral phases in soils, river and marine sediments. Such an approach comparing drainage basin and adjacent continental margin signatures may prove crucial in delineating the nature and provenance of signals preserved in marine sedimentary sequences in the receiving basin, and hence for informed interpretation of corresponding downcore records. Specific questions include the following: (i) to what extents do offshore sedimentary signatures reflect characteristics of the modern-day basin, and what is their provenance? (ii) How and to what degree are organic and mineral matter (de-)coupled during mobilization and transfer from source to sink? By addressing these questions, we aim to improve our understanding of carbon flow through river basins, as well as to better inform interpretation of geochemical signals preserved in river-dominated sedimentary sequences.

\section{Materials and methods}

\subsection{Study area}

The Godavari River is the largest monsoon-fed river basin and the third largest river (behind Ganges and Brahmaputra) of India, delivering $170 \mathrm{Tg}$ per year of sediment and $1.5 \mathrm{Tg}$ per year of OC to the BoB (Biksham and Subramanian, 1988; Ludwig et al., 1996). It originates from Sahyadris in the Western Ghats and flows toward the east-south-east across the Indian peninsula, traversing various geological and vegetation gradients before emptying into the BoB (Fig. 1). Four major tributaries (Purna, Pranhita, Indravati, and Sabri) drain over $60 \%$ of the basin area, and the modern-day catchment $\left(\sim 3 \times 10^{5} \mathrm{~km}^{2}\right)$ supports a population of about 75 million people (Pradhan et al., 2014). The basin experiences pronounced seasonality with marked wet and dry seasons, and the majority of annual rainfall occurs during June-September and is associated with the moist south-west monsoon winds. The Western Ghats act as an orographic barrier (Fig. 1a and b), strongly affecting the precipitation pattern over peninsular India, with monsoonal rains falling preferentially between the coast and the Ghats, leaving much of the inland region with lower precipitation (Gunnel et al., 2007). As a result, the upper river catchment, spanning the Deccan Plateau, is characterized by arid to semi-arid vegetation and lower annual precipitation $\left(<800-1200 \mathrm{~mm} \mathrm{yr}^{-1}\right)$, while moist and deciduous vegetation and higher annual precipitation (1600$3200 \mathrm{~mm} \mathrm{yr}^{-1}$ ) typifies the lower basin (Asouti and Fuller, 2008) (Fig. 1c, panels i and ii).

The underlying rock formations exert significant control on sediment and solute transport by rivers. Based on their erodibility, rock formations in the Godavari are categorized as follows (Biksham and Subramanian, 1988): (a) Deccan Traps, which are volcanic in origin and of Tertiary age, are known for their distinct spheroidal weathering and high fluvial erosion (Subramanian, 1981). The whole Deccan Plateau (representing $\sim 48 \%$ of the basin area; Fig. 1) is covered by $10-40 \mathrm{~cm}$ thick black clay loam, which serves as a source of riverine sediments; (b) sedimentary rocks (mostly sandstones) of Mesozoic-Cenozoic age located in the central and lower part of the catchment ( $\sim 11 \%$ of basin area) are known for their high degree of erodibility; (c) Precambrian granites, charnockites, and similar hard rocks $(\sim 39 \%$ of total basin area) are characterized by low erodibility. River tributaries draining through these relatively stable rock formations (e.g. Sabri and Indravati) carry low sediment loads. Compared to the Deccan volcanic rocks, soils derived from the erosion of sedimentary and Precambrian rocks prevalent in the eastern segment of the basin are generally thinner $(<15 \mathrm{~cm})$ and reddish-yellowish in colour (Bhattacharyya et al., 2013). Sediments transported by the Godavari are thus mostly derived from the Deccan Traps and from granitoids of the Indian Craton (Biksham and Subramanian, 1988). These contrasting bedrocks manifest themselves in corresponding isotopic signatures, where relatively young Deccan volcanic rocks are characterized by highly radiogenic mantle-derived material $\left(\varepsilon \mathrm{Nd}=-1 \pm 5,{ }^{87} \mathrm{Sr} /{ }^{86} \mathrm{Sr}=0.701\right)$, while the relatively old Indian Craton is unradiogenic $(\varepsilon \mathrm{Nd}=-35 \pm 8$, ${ }^{87} \mathrm{Sr} /{ }^{86} \mathrm{Sr}=0.716$ ) (Giosan et al., 2017; Tripathy et al., 2011) (Fig. 1c, panel iii).

Spatial variations in soil types and coverage of the basin are described by Gupta et al. (1997). Black soils (Vertisols, Vertic Inceptisols, and Entisols) are prevalent in the central and western parts of the basin. The eastern part of the basin is dominated by red-yellow soils (Alfisols and Luvisols), and in the estuarine-deltaic region, soil type varies over relatively short distances (Gupta et al., 1997) (Fig. 1c, panel iv).

The Godavari River emerges from the Eastern Ghats on the coastal plain near Rajahmundry, from where it has built a large delta in conjunction with the neighbouring Krishna River that empties into the $\mathrm{BoB}$ and delivers sediment to the pericratonic Krishna-Godavari Basin (Manmohan et al., 2003). The latter, located in the central part of the eastern continental margin of peninsular India, formed as a result 
of the down-warping of the eastern segment of the Indian Shield subsequent to the break-up of Gondwanaland (Murthy et al., 1995). Unlike the Himalayan rivers that adjust to largemagnitude monsoon floods by increasing their width and width-depth ratio (Coleman, 1969), the incised channel of the Godavari responds to the increase in discharge by decreasing its width-depth ratio (Kale, 2002). Because of cohesive banks and incised channel morphology in the lower basin, shifts in channel position are rare, resulting in limited overbank sediment deposition and restricted areal extent of the floodplain. As a consequence of this limited accommodation space in the lower basin, fluvial sediments either accumulate in the delta or are exported to the BoB. Furthermore, sediment trapping on the continental shelf is minimal because the shelf in front of the Godavari Delta is narrow (generally $<10 \mathrm{~km}$ ), promoting more rapid and direct transport of fluvial sediments to the continental slope. Also, satellite images reveal a plume of suspended river sediments from the Godavari mouth out into the BoB past the continental shelf, confirming delivery of riverine sediments to the slope (Sridhar et al., 2008). Therefore, no major lags in or modifications to the fluvial signals between discharge from the river and deposition on the continental slope are expected. This sedimentary regime of the Godavari system thus allows for relatively straightforward interpretation of sediment sources and transfer processes (Giosan et al., 2017) and facilitates direct comparison between characteristics of drainage basin and BoB sediments.

Damming of the Godavari River and its tributaries has increased tremendously over the past several decades, with more than 300 hydrologic projects of various sizes currently in operation that regulate water discharge and sediment transport to the BoB. For the purpose of our study, we divide the drainage basin into two major sections: the upper-basin (UB) section (source to Pranhita River tributary) and lower-basin (LB) section (Pranhita to the BoB) as this captures the major contrast in bedrock lithology and vegetation between the two segments, allowing for assessment and attribution of signals emanating from these major parts of the river basin. It should be noted that though the Pranhita River has half of its catchment in the upper basin, about $94 \%$ of its total suspended particulate matter (SPM) flux is derived from the Wardha and Wainganga rivers in the lower reaches of the catchment (Balakrishna and Probst, 2005; Fig. 1), justifying the classification of Pranhita into the lower basin.

\subsection{Sampling}

\subsubsection{River basin}

River sediments (flood deposits from the flank of the river and riverbed deposits) and soil sampling was carried out in February-March 2015, coinciding with the dry season. Sampling locations are shown in Fig. 1b, with additional details provided in Table S1 in the Supplement. Soil sampling sites were chosen to represent the dominant soil type of the given region, and were sampled on level ground and close to rivers. Surface soils and litter $(0-5 \mathrm{~cm})$ were collected using a small hand shovel. Additionally, undisturbed soil profiles were obtained at some targeted locations (Fig. 1b) using a metre-long coring device, and where possible were sampled to bedrock. Soil cores were then sub-sectioned into a 0 $5 \mathrm{~cm}$ ("shallow/surface") interval, and every $10 \mathrm{~cm}$ thereafter ("deep"). These depths were chosen to represent the likely sources of shallow (surface run-off) and deeper (e.g. bank) soil erosion and supply to nearby streams. At a few sites, road constructions provided access to complete soil sections that were sampled at $10 \mathrm{~cm}$ intervals.

Riverbed sediments were collected from the middle of the stream either with a Van Veen grab sampler from bridges or with a hand shovel where the river was very shallow. The sampling sites were selected as being representative of the local depositional settings of the rivers and its tributaries, and they mostly comprise areas dominated by bedload sediments (channel thalweg) with particle sizes ranging from $<2 \mu \mathrm{m}$ (clay) to $2 \mathrm{~mm}$ (coarse sand) and minor proportions of pebbles and plant debris. Where a tributary joins the mainstem of the Godavari, sampling was conducted before the confluence of the two rivers and shortly downstream of the confluence so as to assess the integrated signal of the sub-catchments.

Where present, riverbank sediments that represent loose and unconsolidated freshly deposited suspended sediments were also collected with a hand shovel and as close to the main river stem as possible. Upon arrival at ETH Zurich, all sediment and soil samples were stored frozen $\left(-20^{\circ} \mathrm{C}\right)$, then freeze-dried and subsequently dry-sieved to $<2 \mathrm{~mm}$ to remove the rock fragments and plant debris. About 20 soils and sediment samples were further milled to powder using an agate ball mill.

\subsubsection{Offshore}

A piston offshore sediment (OS) core NGHP-01-16A $\left(16.59331^{\circ} \mathrm{N}, 82.68345^{\circ} \mathrm{E}, 1268 \mathrm{~m}\right.$ water depth) was collected near the mouth of the Godavari River in the $\mathrm{BoB}(\mathrm{Col}-$ lett et al., 2014) (Fig. 1b). The $8.5 \mathrm{~m}$ long core spanning the entire Holocene ( $\sim 11 \mathrm{kyr}$; Ponton et al., 2012) was analysed for sedimentological, mineralogical, and geochemical characteristics. Due to the top $25 \mathrm{~cm}$ of the core being exhausted by prior investigations, our results are augmented with those from Ponton et al. (2012) and Giosan et al. (2017). The sediment depth corresponding to $\sim 4.5 \mathrm{kyr} \mathrm{BP}$ (ca. $515 \mathrm{~cm}$ ), representing the onset of the vegetation shift in peninsula India during the Holocene, was designated as the boundary between the early (EH) and late Holocene (LH). 


\subsection{Sample treatment and measurements}

\subsubsection{Mineral surface area}

About $1 \mathrm{~g}$ dry weight (gdw) from each soil and sediment sample (unground) was combusted at $350^{\circ} \mathrm{C}$ for $6 \mathrm{~h}$ in order to remove the organic matter. The samples were then outgassed at $350{ }^{\circ} \mathrm{C}$ for $2 \mathrm{~h}$ in a vacuum oven to remove adsorbed moisture on the surface before analysis. Prior to analysis, samples were homogenized in an agate mortar, using a plastic pestle to avoid crushing mineral grains. Surface area of the mineral components of the sediment was analysed by the multi-point BET $\mathrm{N}_{2}$ adsorption method using a Quantachrome Monosorb Analyzer (Wakeham et al., 2009). The precision on duplicates of alumina standards was better than $1 \%$.

\subsubsection{Grain size}

An aliquot $(\sim 0.5 \mathrm{gdw})$ of combusted $\left(350^{\circ} \mathrm{C}, 6 \mathrm{~h}\right)$ sediment and soil samples processed for mineral surface area analysis was treated with $10-15 \mathrm{~mL}$ of dissolved $\left(40 \mathrm{~g} \mathrm{~L}^{-1}\right)$ sodium pyrophosphate $\left(\mathrm{Na}_{4} \mathrm{P}_{2} \mathrm{O}_{7} \cdot 10 \mathrm{H}_{2} \mathrm{O}\right)$ for about $12 \mathrm{~h}$ to disaggregate the sediment grains. Sediment and soil grain size distributions were measured using a Malvern Mastersizer 2000 Laser Diffraction Particle Analyser that characterizes particle sizes ranging from 0.04 to $2000 \mu \mathrm{m}$. Sediment and soil samples were measured in triplicate, with average median $(d 50)$ values reported. The standard deviation on triplicate analysis was better than $1 \%$.

\subsubsection{Sediment mineralogy}

Eight sediment and soil samples were selected to represent varying regions and lithologies of the Godavari basin, and 12 samples taken from various depths in offshore core 16A were selected for X-ray diffraction (XRD) analysis. About $1 \mathrm{~g}$ of bulk sediment was wet-milled in ethanol using a McCrone Micronising Mill. The milled sample was then passed through a $20 \mu \mathrm{m}$ sieve and transferred into a ceramic bowl. Mineral grains larger than $20 \mu \mathrm{m}$ were reintroduced into the mill and the process was repeated. The milled samples were dried overnight at $65^{\circ} \mathrm{C}$. The dried sample was pulverized and homogenized using a Fritsch Pulverisette 23 milling device. The resulting sample was then gently loaded onto a sample holder and packed continuously using razor blades to form a randomly oriented powdered specimen with a smooth surface which minimizes preferential orientation (Zhang et al., 2003). A second sample preparation was carried out, producing textured specimens for enhancement of the basal reflections of layered silicates and thereby facilitating their identification. The changes in the basal spacing in the XRD pattern by intercalation of organic compounds (e.g. ethylene glycol) and after heating $\left(2 \mathrm{~h}, 550^{\circ} \mathrm{C}\right)$ were used for identification of smectite and kaolinite, respectively. XRD measurements were performed on a Bruker AXS D8 Theta-Theta diffractometer using $\mathrm{Co}-\mathrm{K} \alpha$ radiation. The instrument was equipped with an automatic theta-compensating divergence and anti-scattering slit, primary and secondary Soller slits and a Sol-X solid state detector. The phase composition was then determined using the DIFFRACplus software. Mineral phases were identified on the basis of the peak position and relative intensity in comparison to the PDF-2 database (International Centre for Diffraction Data). Quantification of minerals was achieved with the BGMN/AutoQuan software using Rietveld refinement (Bergmann and Kleeberg, 1998; Bish and Plötze, 2011).

\subsubsection{Bulk elemental and isotopic analysis}

Aliquots of freeze-dried sediment or soil samples $(\sim 50-$ $200 \mathrm{mg}$ ) were weighed into pre-combusted silver boats (Elementar) and fumigated in a closed desiccator in the presence of $12 \mathrm{M} \mathrm{HCl}\left(70^{\circ} \mathrm{C}, 72 \mathrm{~h}\right.$ ) to remove inorganic carbon (Bao et al., 2016; Komada et al., 2008). The samples were subsequently neutralized and dried over $\mathrm{NaOH}$ pellets to remove residual acid. The sample was then wrapped in tinfoil boats (Elementar), pressed, and analysed using a combined elemental analyser, isotope ratio mass spectrometer, and accelerator mass spectrometer (EA-IRMS-AMS) system at ETH Zurich (McIntyre et al., 2016; Wacker et al., 2010). The instrumental set-up, blank assessment, accuracy, and reproducibility for the data presented here have been previously reported in McIntyre et al. (2016).

For down-core sediments, ${ }^{14} \mathrm{C}_{\mathrm{OC}}$ values were decaycorrected for ${ }^{14} \mathrm{C}$ loss since time of deposition (Eq. 1; Stuiver and Polach, 1977). This decay correction is necessary to facilitate comparison of ${ }^{14} \mathrm{C}$ values between the sediment core and ${ }^{14} \mathrm{C}$ signatures in the modern river basin. The decaycorrected radiocarbon level, $\Delta$, is calculated as follows:

$\Delta=\left(F^{14} \mathrm{C} e^{\lambda(1950-x)}-1\right) \cdot 1000$,

where $F^{14} \mathrm{C}=$ measured fraction modern value of ${ }^{14} \mathrm{C}$, $\lambda=(\ln 2) / 5730 \mathrm{yr}^{-1}\left(5730\right.$ years is the true half-life of $\left.{ }^{14} \mathrm{C}\right)$, and $x=$ year of deposition. The year of sediment deposition is estimated from the age model of Ponton et al. (2012) (Table S2). Henceforth, all bulk ${ }^{14} \mathrm{C}$ values for the offshore sediment core refer to the $\Delta$ value. However, it should be noted that the influence of "bomb ${ }^{14} \mathrm{C}$ ", resulting from aboveground nuclear weapons testing in the mid-20th century, on modern-day Godavari Basin ${ }^{14} \mathrm{C}$ values is not accounted for in this calculation

\subsubsection{Compound-specific stable carbon isotopic analysis}

Freeze-dried and homogenized sediment samples (30$100 \mathrm{~g}$ ) were microwave-extracted with dichloromethane (DCM) : methanol $(\mathrm{MeOH})(9: 1 v / v)$ for $25 \mathrm{~min}$ at $100^{\circ} \mathrm{C}$ (MARS, CEM Corporation). The 20 selected milled sam- 
ples were extracted, using an accelerated solvent extractor (ASE 350, Dionex, Thermo-Scientific), with DCM: $\mathrm{MeOH}$ $(9: 1 \mathrm{v} / \mathrm{v})$ at $100^{\circ} \mathrm{C}$ and $7.6 \mathrm{MPa}$. The total lipid extracts (TLEs) were dried under $\mathrm{N}_{2}$ and then saponified with $0.5 \mathrm{M}$ potassium hydroxide $(\mathrm{KOH})$ in $\mathrm{MeOH}\left(70^{\circ} \mathrm{C}\right.$ for $\left.2 \mathrm{~h}\right)$. A "neutral" fraction was obtained by back-extraction with hexane after the addition of Milli-Q water with sodium chloride $(\mathrm{NaCl})$ to aid separation. The "acid" fraction was obtained by back-extraction of the hydrolysed solution with hexane:DCM $(4: 1 v / v)$ after adjusting the $\mathrm{pH}$ to $\leq 2$. The acid fraction was transesterified with $\mathrm{MeOH}: \mathrm{HCl}$ (hydrochloric acid) $(95: 5 \mathrm{v} / \mathrm{v})$ of known isotopic composition at $70^{\circ} \mathrm{C}$ for $12-16 \mathrm{~h}$ in order to yield corresponding fatty acid methyl esters (FAMEs). The resulting FAMEs were then purified using silica gel-impregnated silver nitrate $\left(\mathrm{AgNO}_{3}-\right.$ $\mathrm{SiO}_{2}$ ) column chromatography to remove unsaturated homologues. Aliquots of the FAMEs obtained from each sample were measured in duplicate by gas chromatography-isotope ratio mass spectrometry (GC-IRMS) using an HP 6890 GC coupled with a Thermo-Delta V IRMS system. The ${ }^{13} \mathrm{C}$ values of fatty acids (FAs) were subsequently corrected for the contribution of the added methyl carbon and respective errors were propagated (Tao et al., 2015). The average uncertainty is $0.3 \%$ for the FAs. Results are reported relative to Vienna Pee Dee Belemnite (VPDB) (Craig, 1953).

\section{Results}

\subsection{Surface and deep soils}

Both surface and deep soils from the upper basin are highly enriched in smectite (30-50\% of total minerals) with lesser abundances of kaolinite and illite + chlorite (Fig. 2). On the other hand, soils from the lower basin are mostly quartzo-feldspathic (25-40\% of total minerals) with minor amounts of kaolinite (Fig. 2; see also Kulkarni et al., 2015; Subramanian, 1981). Total organic carbon (TOC) contents of Godavari River basin soils range from 0.1 to $1.8 \%$ (mean $=0.6 \pm 0.4 \%, n=67$; Table S1). The highest TOC values were found for surface soils close to the headwaters of the river (Fig. 3a). The highest and lowest values for median grain size (GS) (970 and $5.9 \mu \mathrm{m}$, respectively) are recorded in surface soils from the upper part of the basin (Table S1). High mineral surface area (MSA) values are common in upperbasin soils (mean $=42 \pm 18 \mathrm{~m}^{2} \mathrm{~g}^{-1}, n=51$ ), with lower values in those from the lower basin (mean $=21 \pm 11 \mathrm{~m}^{2} \mathrm{~g}^{-1}$, $n=16$; Fig. 3b). MSA-normalized OC (a term that expresses OC loading on mineral surfaces) values of soils range from 0.03 to $0.84 \mathrm{mg} \mathrm{OC} \mathrm{m}^{-2}$ (mean $=0.20 \pm 0.15 \mathrm{mg} \mathrm{OC} \mathrm{m}^{-2}$ ). Due to the relatively low TOC values and high MSA values, the majority of the soils plot outside the range of typical river-suspended sediments as defined by Blair and Aller (2012).

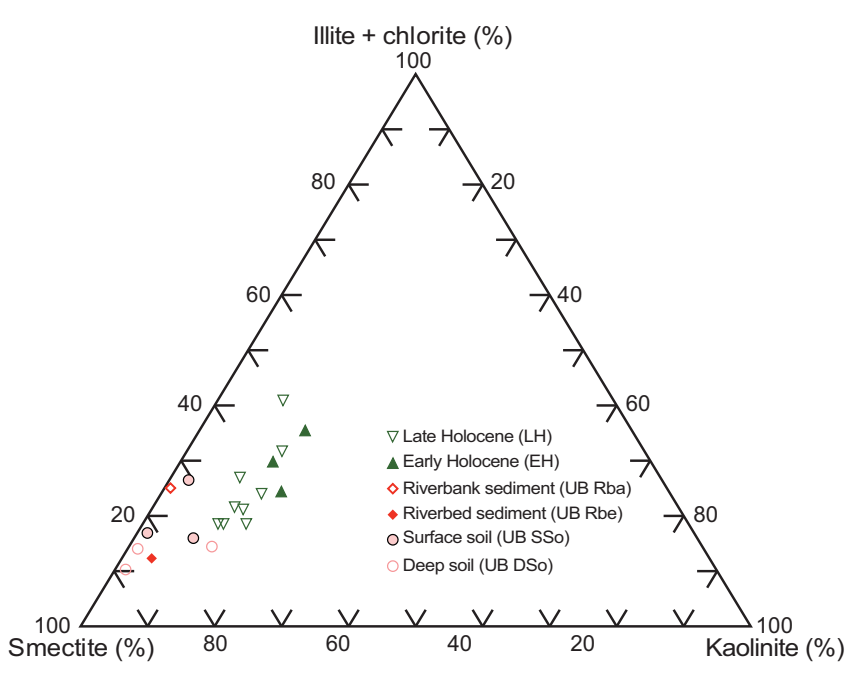

Figure 2. Phyllosilicate mineral composition of the Godavari River basin and offshore sediments.

Lipid analyses from river sediments and soils produced LCFA with an average chain length (ACL) consistently $>28$ and similar stable carbon isotope values among $\mathrm{C}_{26}-\mathrm{C}_{32} \mathrm{FA}$ homologues (Fig. S1). Thus, isotopic values are reported as mean weighted averages of $\mathrm{C}_{26}-\mathrm{C}_{32}$ FA (Table S1). LCFAs of soils range from 4 to $264 \mu^{-1} \mathrm{~g}^{-1} \mathrm{OC}$ with extremely low concentrations in the surface soils of the lower basin (mean $=10 \pm 3 \mu \mathrm{g} \mathrm{g}^{-1} \mathrm{OC}, n=8$ ). SA-normalized $\mathrm{C}_{26}-\mathrm{C}_{32}$ FA concentrations (FA loadings) of surface soils range from 0.1 to $4.6 \mu \mathrm{g} \mathrm{LCFA} \mathrm{m}^{-2}$ (mean $=2.0$ and $0.3 \mu \mathrm{g} \mathrm{LCFA} \mathrm{m}{ }^{-2}$ for upper-basin and lower-basin soils, respectively) and decrease progressively towards the estuary. The average $\delta^{13} \mathrm{C}_{\mathrm{OC}}$ value of upper-basin soils $(-17.9 \pm 3.1 \%$; $n=51)$ contrasts sharply with that of soils from the lower basin $(-23.2 \pm 2.0 \%$; $n=16$, Fig. 3c). A similar $\sim 5 \%$ o difference was observed in corresponding $\delta^{13} \mathrm{C}_{\mathrm{LCFA}}$ values, which average $-24.1 \%$ o $( \pm 0.3 \%$ o, $n=39)$ in the upper basin and $-30.6 \%$ o $( \pm 0.3 \%$ o $n=8)$ in the lower basin.

The soil depth profiles generally show a decrease in TOC contents from top to bottom, accompanied with relatively invariant (upper basin) or increasing (lower basin) $\delta^{13} \mathrm{C}_{\text {LCFA }}$ values (Fig. S2). Corresponding $\Delta^{14} \mathrm{COC}_{\mathrm{OC}}$ values of soils range from -337 to $+132 \%$, with the most depleted values recorded in deeper soil horizons (Fig. 3d).

\subsection{Riverbed and riverbank sediments}

The median GS of riverbed and riverbank sediments varied between 8 and $851 \mu \mathrm{m}$ (Table S1). Generally, the upper basin is characterized by fine-grained sediments $(9-50 \mu \mathrm{m}$; mean $=23 \pm 11 \mu \mathrm{m}, n=12$ ) and the lower basin by coarsegrained sediments $(136-852 \mu \mathrm{m}$; mean $=456 \pm 288 \mu \mathrm{m}$, $n=6$ ) (Table S1), except in the delta where finer-grained material $(8-116 \mu \mathrm{m}$, mean $=51 \pm 57 \mu \mathrm{m}, n=3)$ again predominates. Similarly, MSA values show consistently high val- 

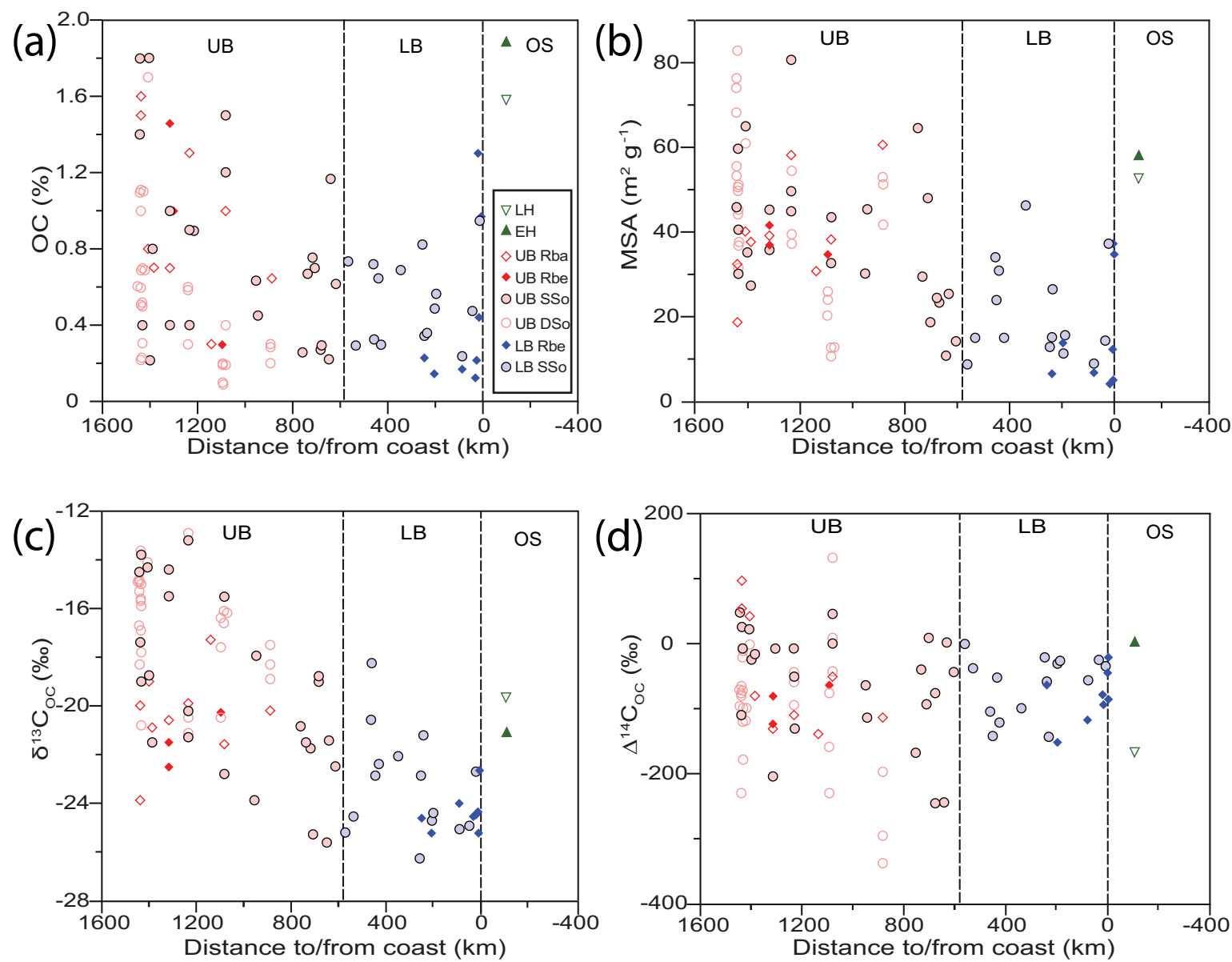

Figure 3. (a) Total organic carbon (OC; \%). (b) Mineral surface area (MSA) $\left(\mathrm{m}^{2} \mathrm{~g}^{-1}\right)$. (c) Bulk OC stable carbon isotope $\delta^{13} \mathrm{C}_{\mathrm{OC}}(\%)$ ). (d) Bulk OC radiocarbon contents $\left(\Delta^{14} \mathrm{C}_{\mathrm{OC}}\right)(\%$ ) in the Godavari basin and adjacent margin. Symbols key and abbreviations are as for Figs. 1 and 2. Average values of early $(\mathrm{EH})$ and late Holocene $(\mathrm{LH})$ sediment samples are shown.

ues $\left(19-60 \mathrm{~m}^{2} \mathrm{~g}^{-1}\right.$; mean $\left.=39 \pm 11 \mathrm{~m}^{2} \mathrm{~g}^{-1}, n=12\right)$ in the upper basin, markedly lower values in the lower basin $(2-$ $14 \mathrm{~m}^{2} \mathrm{~g}^{-1}$; mean $=6 \pm 4 \mathrm{~m}^{2} \mathrm{~g}^{-1}, n=6$ ), and intermediate values in the delta $\left(12-37 \mathrm{~m}^{2} \mathrm{~g}^{-1}\right.$; mean $=28 \pm 13 \mathrm{~m}^{2} \mathrm{~g}^{-1}$, $n=3$; Table S1, Fig. $3 \mathrm{~b}$ ). There is a weak positive linear correlation between MSA and GS $\left(r^{2}=0.33\right.$ and 0.36 for riverbank and riverbed sediment, respectively). Samples with lower GS and higher MSA generally have higher TOC contents $(0.3-1.6 \%$; Fig. 3a and b). Conversely, sediments with coarser GS and lower MSA have low TOC contents $(0.1-0.4 \%)$. OC loading values, which range from 0.09 to $0.80 \mathrm{mg} \mathrm{OC} \mathrm{m}^{-2}\left(\right.$ mean $\left.=0.29 \pm 0.18 \mathrm{mg} \mathrm{OC} \mathrm{m}^{-2}\right)$ are generally low compared to typical river sediments (Fig. 4; Blair and Aller, 2012; Freymond et al., 2018). The relative phyllosilicate mineral content of the two upper-basin sediment samples that were analysed shows that smectite predominates (65 and $72 \%$ for riverbed and riverbank, respectively) while the kaolinite content is higher in the riverbed $(10 \%$ vs. $1 \%$ for riverbank). The remainder of the phyllosilicates comprises illite and chlorite (25 and $27 \%$ for riverbed and riverbank, respectively; Fig. 3).

Concentrations of long-chain $\left(\mathrm{C}_{26-32}\right)$ FAs in riverine sediments range from 7 to $187 \mu \mathrm{gg}^{-1} \mathrm{OC}$, with the lowest concentrations $\left(7-16 \mu \mathrm{g} \mathrm{g}^{-1} \mathrm{OC}\right)$ found in the lowerbasin riverbed sediments, and the highest concentrations (67-187 $\mathrm{\mu g} \mathrm{g}^{-1} \mathrm{OC}$ ) in upper-basin riverbank sediments (Table $\mathrm{S} 1$ ). The lower-basin riverbed sediments have very low $\mathrm{C}_{26-32}$ FA concentrations (mean $=9 \pm 4 \mu \mathrm{g} \mathrm{g}^{-1} \mathrm{OC}, n=4$ ), while those of upper-basin riverbed sediments are below detection. Bulk $\delta^{13} \mathrm{C}_{\mathrm{OC}}$ values for all river sediments range from -17.3 to $-25.2 \%$. The most enriched $\delta^{13} \mathrm{C}_{\mathrm{OC}}$ value was observed in the upper basin (Fig. 3c), where samples yielded an average value of $-20.6 \%$ o $( \pm 0.3 \%, n=12)$. The most depleted $\delta^{13} \mathrm{C}_{\mathrm{OC}}$ value was recorded in the lower basin, where fluvial sediments averaged $-24.1 \%$ o $( \pm 0.3 \%$ o, $n=9)$. Compound-specific $\delta^{13} \mathrm{C}$ analysis of the LCFAs $\left(\delta^{13} \mathrm{C}_{\mathrm{LCFA}}\right)$ of river sediments yielded values between -24.8 and $-32.8 \%$. Similar to $\delta^{13} \mathrm{C}_{\mathrm{OC}}$, the most enriched $\delta^{13} \mathrm{C}_{\mathrm{LCFA}}$ value $(-24.8 \%$, mean $=-27.4 \pm 0.3 \%$, 


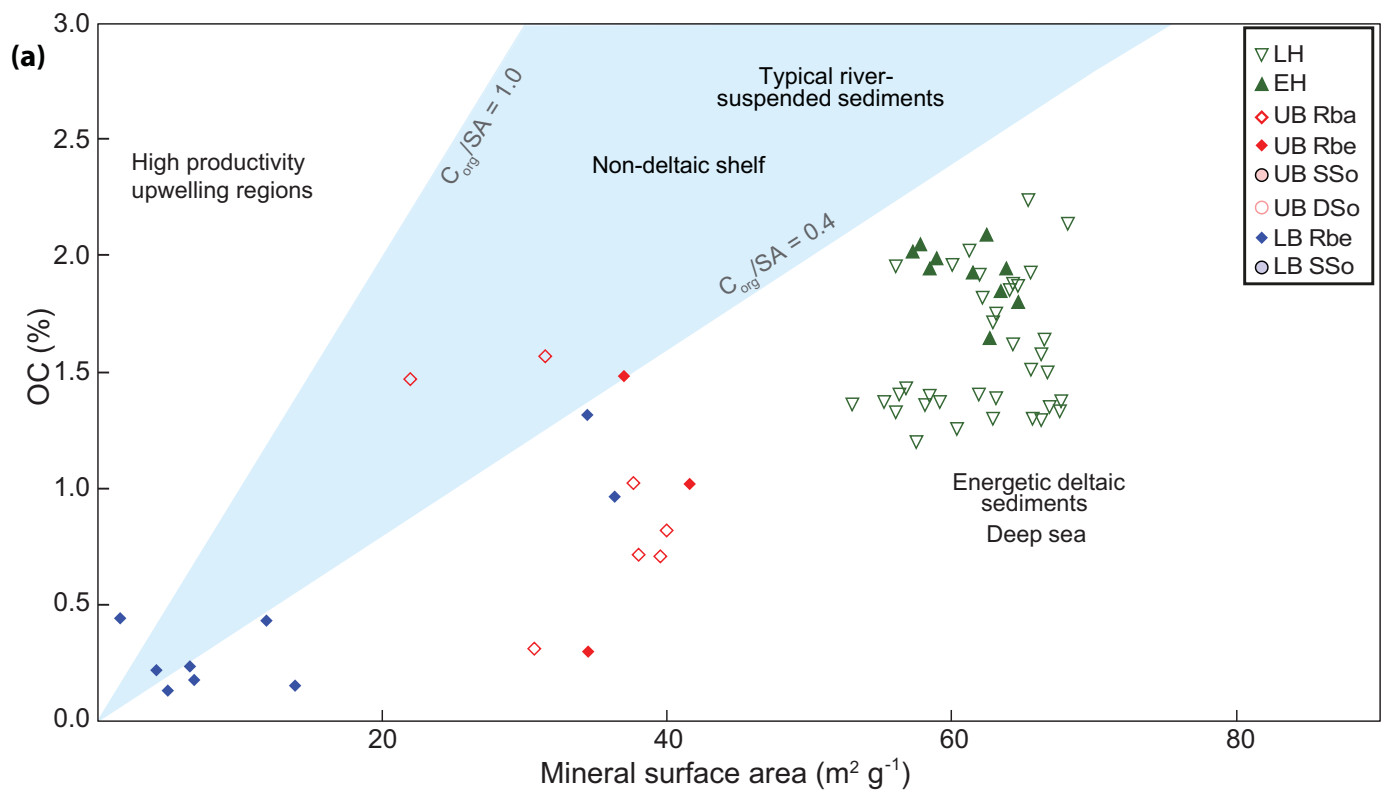

Sand

Clay

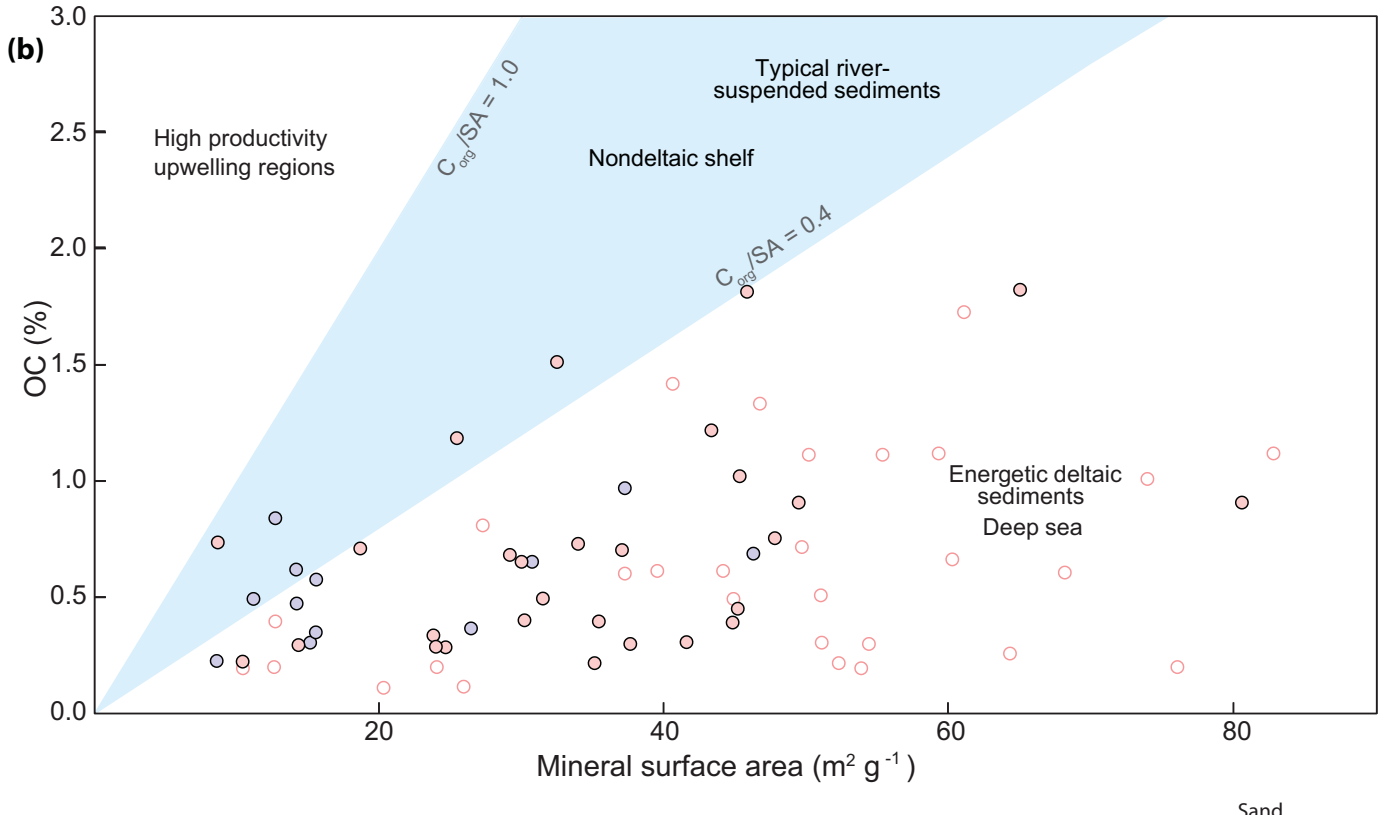

$\stackrel{\leftrightarrow}{\longleftrightarrow \text { Clay }}$

Figure 4. (a) Organic carbon loadings for river sediments and marine sediments. (b) OC vs. MSA for soils samples within the basin. Symbol key and abbreviations are as for Figs. 1 to 3. Blue shaded area corresponds to range typical for river-suspended and non-deltaic sediments as described by Blair and Aller (2012). 
$n=6)$ was recorded in the upstream section and the most depleted value $(-32.8 \%$, mean $=-31.3 \pm 0.3 \%, n=4)$ was observed in the downstream segment. The $\Delta^{14} \mathrm{C}_{\mathrm{OC}}$ values of river sediments vary between -151 and $97 \%$ (Fig. 3d) with no clear systematic difference between the upstream and downstream sections of the basin.

\subsection{River-proximal marine sediments}

The TOC content of sediments from core 16A varies from 1.2 to $2.1 \%$, and generally decreases from the bottom to the top of the core, resulting in mean values of $1.9 \pm 0.1 \%(n=10)$ and $1.6 \pm 0.3 \%(n=37)$ for the early and late Holocene, respectively (Table S2, Fig. 3a). The GS and MSA are both fairly uniform, with values ranging from 4.0 to $5.2 \mu \mathrm{m} \quad($ mean $=4.5 \pm 0.3 \mu \mathrm{m}$ ) and 54 to $72 \mathrm{~m}^{2} \mathrm{~g}^{-1} \quad\left(\right.$ mean $\left.=63 \pm 4 \mathrm{~m}^{2} \mathrm{~g}^{-1}\right)$, respectively. OC loadings decrease progressively from the early $\left(\right.$ mean $=0.31 \pm 0.03 \mathrm{mg} \mathrm{OC} \mathrm{m}^{-2}$ ) to late Holocene (mean $=0.25 \pm 0.04 \mathrm{mg} \mathrm{OC} \mathrm{m}^{-2}$ ). The range OC loading values of the core sediments $\left(0.19-0.35 \mathrm{mg} \mathrm{OC} \mathrm{m}^{-2}\right)$ are within the range of values expected for deltaic and deepsea sediments (Fig. 4; Blair and Aller, 2012). Relative abundances of phyllosilicate minerals of the analysed core sediments show that early Holocene sediments have slightly higher kaolinite and illite + chlorite contents than the late Holocene sediments, whereas the smectite contents of late Holocene sediments are slightly higher (Fig. 2).

Concentrations of LCFA in the core vary between 49 and $519 \mu \mathrm{g} \mathrm{g}^{-1}$ OC $\quad\left(\right.$ mean $=181 \pm 95 \mu \mathrm{g} \mathrm{g}^{-1}$ OC $), \quad$ but remain relatively invariant despite the down-core variations in TOC (Table S2). LCFA loading ranges from 0.82 to $4.93 \mu \mathrm{gLCFA} \mathrm{m}^{-2}$, with slightly higher loadings in the late Holocene $\left(\right.$ mean $=2.73 \mu \mathrm{g} \mathrm{LCFA} \mathrm{m}^{-2}$ ) than the early Holocene $\left(\right.$ mean $=2.15 \mu \mathrm{g} \mathrm{LCFA} \mathrm{m}^{-2}$ ). These are similar to the range of LCFA loading values observed in the Danube Basin (Freymond et al., 2018). Stable carbon isotopic compositions of bulk OC $\left(\delta^{13} \mathrm{C}_{\mathrm{OC}}\right)$ range from -19.9 to $-18.2 \%$ (mean $=-18.8 \pm 0.5 \%, n=35$ ) and -20.8 to $-19.8 \%$ (mean $=-20.3 \pm 0.5 \%, n=8)$ for the late and early Holocene, respectively; $\delta^{13} \mathrm{C}_{\mathrm{LCFA}}$ range from -26.75 to $-23.43 \%$ (mean $=-24.89 \pm 1.16 \%, \quad n=34)$ and -28.90 to $-26.84 \%$ o (mean $=-28.01 \pm 0.48 \%, n=11$ ) for the late and early Holocene, respectively. There is a gradual increase in both the $\delta^{13} \mathrm{C}_{\mathrm{OC}}$ and $\delta^{13} \mathrm{C}_{\mathrm{FA}}$ values towards the top of the core. The $\Delta$ values of the measured samples (corrected for decay since deposition) vary between -194.6 and $52.1 \%$, and generally increase with increasing depth (Table S2).

\section{Discussion}

\subsection{Evolution of organic matter-mineral associations in the Godavari River basin}

Soil and sediment samples analysed from the Godavari River and its major tributaries reveal a wide range of grain sizes, mineral surface areas, and TOC contents and compositions. This diversity in characteristics encompasses the range of values reported in previous studies of river sediments and soils within the Godavari catchment (e.g. Balakrishna and Probst, 2005; Pradhan et al., 2014; Kulkarni et al., 2015; Cui et al., 2017). The average TOC content of the upperbasin riverbed sediments is a factor of 2 higher than that of lower-basin sediments $(0.9 \pm 0.5 \%$ vs. $0.4 \pm 0.4 \%$, Table S1), and this distribution reflects the geochemical and sedimentological characteristics of the basin. The relatively high TOC values in the upper basin are likely due to low suspended sediment loads and/or greater proportions of organic debris (Ertel and Hedges, 1985). The modern-day upper Godavari is characterized by low suspended sediment load and relatively high phytoplankton production, resulting in relatively high OC contents in riverbed sediments (Pradhan et al., 2014). In contrast, the lower catchment is more heavily charged with suspended sediments primarily derived from the Pranhita and Indravati rivers draining the Eastern Ghats (Balakrishna and Probst, 2005), with dilution by lithogenic materials resulting in lower observed TOC values in sediments from the lower Godavari basin. The lithological contrast between the upstream and downstream part of the basin may also play an important role in OM distribution between both parts of the basin (see Fig. 1). Erosion of the basalt in the upper basin produces high-MSA, smectite-rich clay mineral assemblages, whereas the erosion of granitic rocks outcropping in the lower basin yields lower-MSA, kaoliniterich assemblages. This lithological contrast likely accounts for the spatial offset in the MSA between the upstream and downstream Godavari (Fig. 2b). The higher TOC values are likely a result of availability of a large mineral surface that provides substrate for OM sorption, stabilization, and protection (Keil et al., 1997; Arnarson and Keil, 2007; Gordon and Goni, 2004; Mayer, 1994b). Organic matter first develops associations with minerals during soil formation (Mayer, 1994a), and these organo-mineral associations that evolve during soil mobilization and erosion are considered to influence the balance of preservation and oxidation (MarinSpiotta et al., 2014; Wang et al., 2014).

Plotting mineral-surface-area normalized OC (OC / MSA) vs. $\delta^{13} \mathrm{C}_{\mathrm{OC}}$ for the river basin sediments and soils reveals marked differences between upper- and lower-basin signals (Fig. 5a). Relatively low $\mathrm{OC}$ loading and higher $\delta^{13} \mathrm{COC}$ values characterize the upper basin whereas high OC loadings and lower $\delta^{13} \mathrm{C}_{\mathrm{OC}}$ values typify the lower basin. This likely reflects the spatial contrast in vegetation and sedimentology or mineralogy within the river basin. Higher $\delta^{13} \mathrm{C}_{\mathrm{OC}}$ 

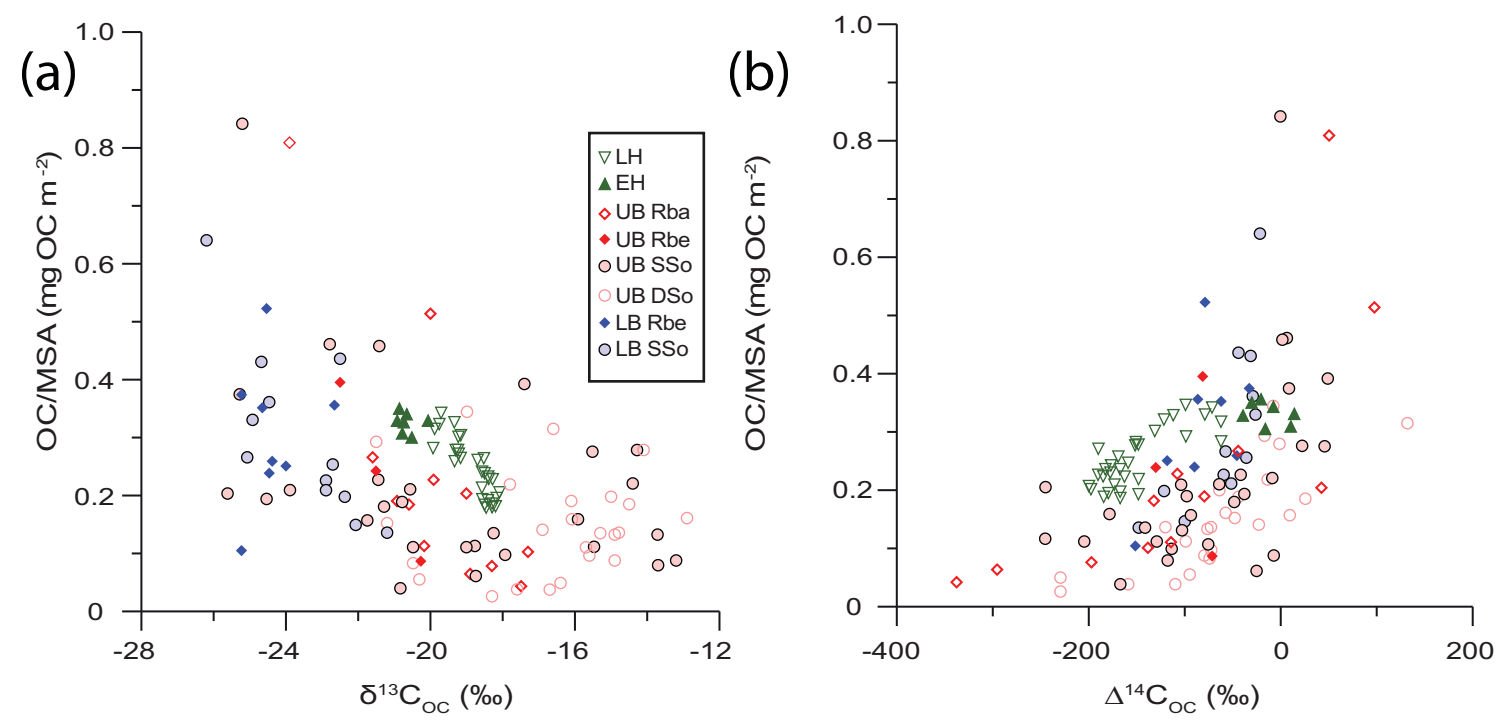

Figure 5. Organic carbon loading vs. (a) $\delta^{13} \mathrm{C}_{\mathrm{OC}}$ and (b) $\Delta^{14} \mathrm{C}_{\mathrm{OC}}$, for Godavari river basin and marine sediment core $16 \mathrm{~A}$. The $\Delta^{14} \mathrm{C}$ values for marine sediments refer to the age-corrected value $(\Delta)$. Symbol key and abbreviations are as for Figs. 1 to 3 .

values in the upper basin reflect a greater preponderance of $\mathrm{C}_{4}$ vegetation in the upper basin while lower OC loadings are attributed to a wide range of factors, including erosion of heavily weathered soils that are relatively depleted in OC and notably enriched in high-surface area smectiterich secondary minerals due to erosion of basalts of the Deccan Plateau (Table S1). This interpretation is consistent with other independent observations within the Godavari Basin and its adjacent margin (Kessarkar et al., 2003; Philips et al., 2014; Shrivastava and Pattanayak, 2002; Srivastava et al., 1998). Assessment of relationships between OC loading and $\Delta^{14} \mathrm{C}_{\mathrm{OC}}$ show that samples with higher OC loadings are generally more enriched in ${ }^{14} \mathrm{C}$ (Fig. 5b). In contrast to bulk OC loadings, LCFA loadings are generally higher in the upper basin (Fig. 6a). These low OC-high LCFA loadings in the upper basin suggest that a large proportion of the OC stabilized onto mineral surfaces derives from terrestrial plants, even at low OC contents. Furthermore, like $\delta^{13} \mathrm{C}_{\mathrm{OC}}$ values, $\delta^{13} \mathrm{C}_{\mathrm{LCFA}}$ values are relatively high in the upper basin (Fig. 6b), indicating a predominant $\mathrm{C}_{4}$ plant origin.

Coupled plots of $\delta^{13} \mathrm{C}$ vs. $\Delta^{14} \mathrm{C}$ have been widely used to elucidate potential sources of $\mathrm{OC}$ in riverine systems, and to delineate various end-member contributions to OC (e.g. Goni et al., 2005; Marwick et al., 2015). The Godavari basin samples exhibit a broad range of $\delta^{13} \mathrm{C}_{\mathrm{OC}}$ values, indicative of mixed vegetation signatures of savanna, tropical grasslands, and tropical forests, as well as aquatic productivity and bedrock inputs, with higher $\delta^{13} \mathrm{C}_{\mathrm{OC}}$ and $\delta^{13} \mathrm{C}_{\mathrm{LCFA}}$ values of upper-basin sediments and soils reflecting the greater proportion of $\mathrm{C}_{4}$ (vs. $\mathrm{C}_{3}$ ) vegetation. When plotted in $\delta^{13} \mathrm{C}$ vs. $\Delta{ }^{14} \mathrm{C}$ space (Fig. 7), the majority of the upper-basin sediments and soils plot within the "soils" end-member and generally cluster around the $\mathrm{C}_{4}$-plant domain, whereas most of the lower-basin sediments and soil plot within the vicinity of the $\mathrm{C}_{3}$-plant end-member. This implies that $\mathrm{OC}$ in the upperbasin sediments mostly derive from $\mathrm{C}_{4}$-plant-derived soil $\mathrm{OM}$ with a minor $\mathrm{C}_{3}$ plant contribution, as evidenced by the clustering of sediments around the $\mathrm{C}_{4}$ end of the soil domain. In the same vein, lower-basin samples point to increased contribution of $\mathrm{C}_{3}$-plant-derived terrestrial $\mathrm{OM}$ (soil).

The spatial decoupling of upper and lower-basin geochemical signatures of river sediments has been largely attributed to the vegetation gradients in the basin. However, the apparent lack of upper-basin signatures in fluvial sediment from the lower reaches could also be a consequence of in-river processes such as loss or replacement of $\mathrm{OC}$ and/or sediment dilution. The general increase in $\Delta^{14} \mathrm{C}$ values from upper to lower basin (Fig. 8) indicates that preferential loss of a younger, more reactive fraction is unlikely. Modern sediment and OC flux data show the highest POC yield $\left(\sim 12 \mathrm{t} \mathrm{km}^{-2} \mathrm{yr}^{-1}\right)$ in the Indravati and Pranhita rivers mostly as a consequence of high runoff that carries large amount of (younger) plant detritus and loose (top) soil from the forest to the mainstream (Balakrishna and Probst, 2005). Presently, more than $470 \mathrm{~km}^{2}$ year ${ }^{-1}$ are lost in the lower basin due to deforestation and forest fire, with maximum forest denudation taking place in the state of Orissa (Silviera, 1993), which is drained by the Indravati River. These processes may destabilize soils and enhance the loss of associated OM to the fluvial network. In contrast, the general decrease in TOC contents towards the lower basin (Fig. 3a) and the downstream increase in SPM (Gupta et al., 1997) points towards dilution of riverine $\mathrm{OC}$ with mineral matter derived from soil erosion in the lower basin. As a result, the OC signatures in the modern-day Godavari river sediments appear to not only reflect the biogeographic and geochemical make-up of the 

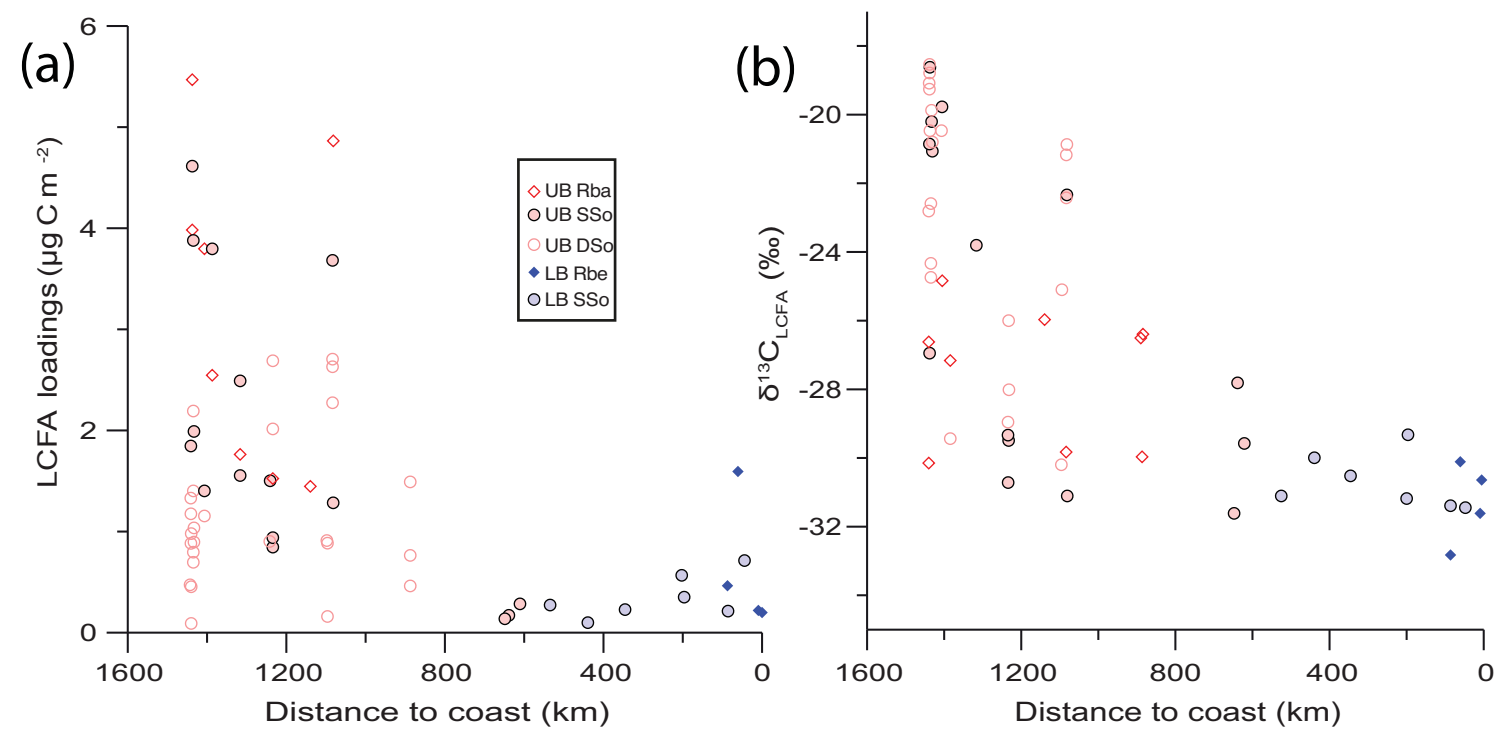

Figure 6. (a) LCFA loading vs. distance to coast. (b) $\delta^{13} \mathrm{C}_{\mathrm{LCFA}}$ vs. distance to coast for river basin samples. Symbol key and abbreviations are as for Figs. 1 to 3.

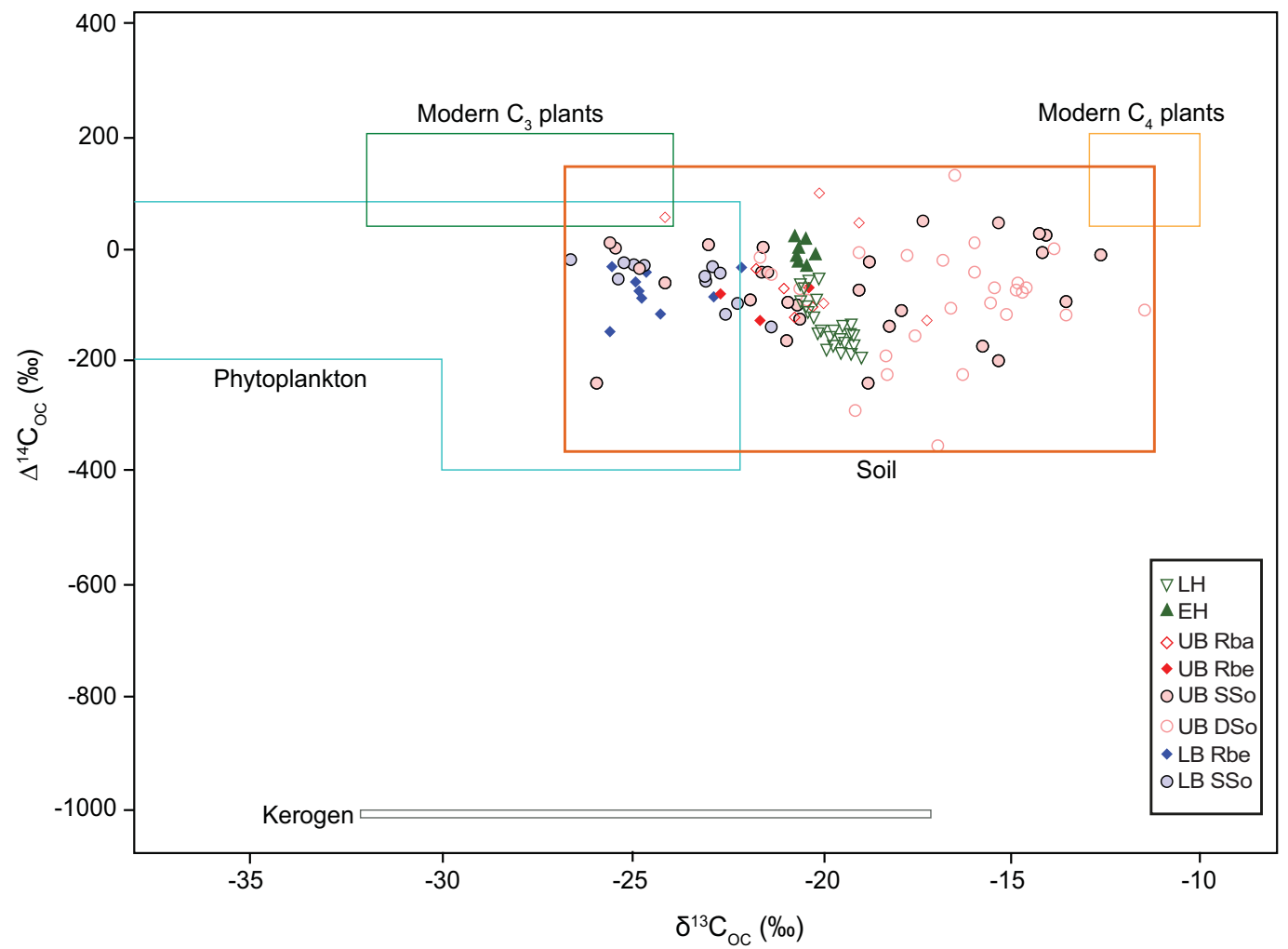

Figure 7. Identifying major sources of organic carbon to the Godavari River and the offshore sediment core using stable $\left(\delta^{13} \mathrm{C}\right)$ and radio $\left(\Delta^{14} \mathrm{C}\right)$ isotopes (Modified after Marwick et al., 2015). The soil end-member is defined based on ranges of values observed within the Godavari and other tropical river systems (e.g. Pessenda et al., 1997; Shen et al., 2001; Trumbore et al., 1989). Symbol key and abbreviations are as for Figs. 1 to 3 . 


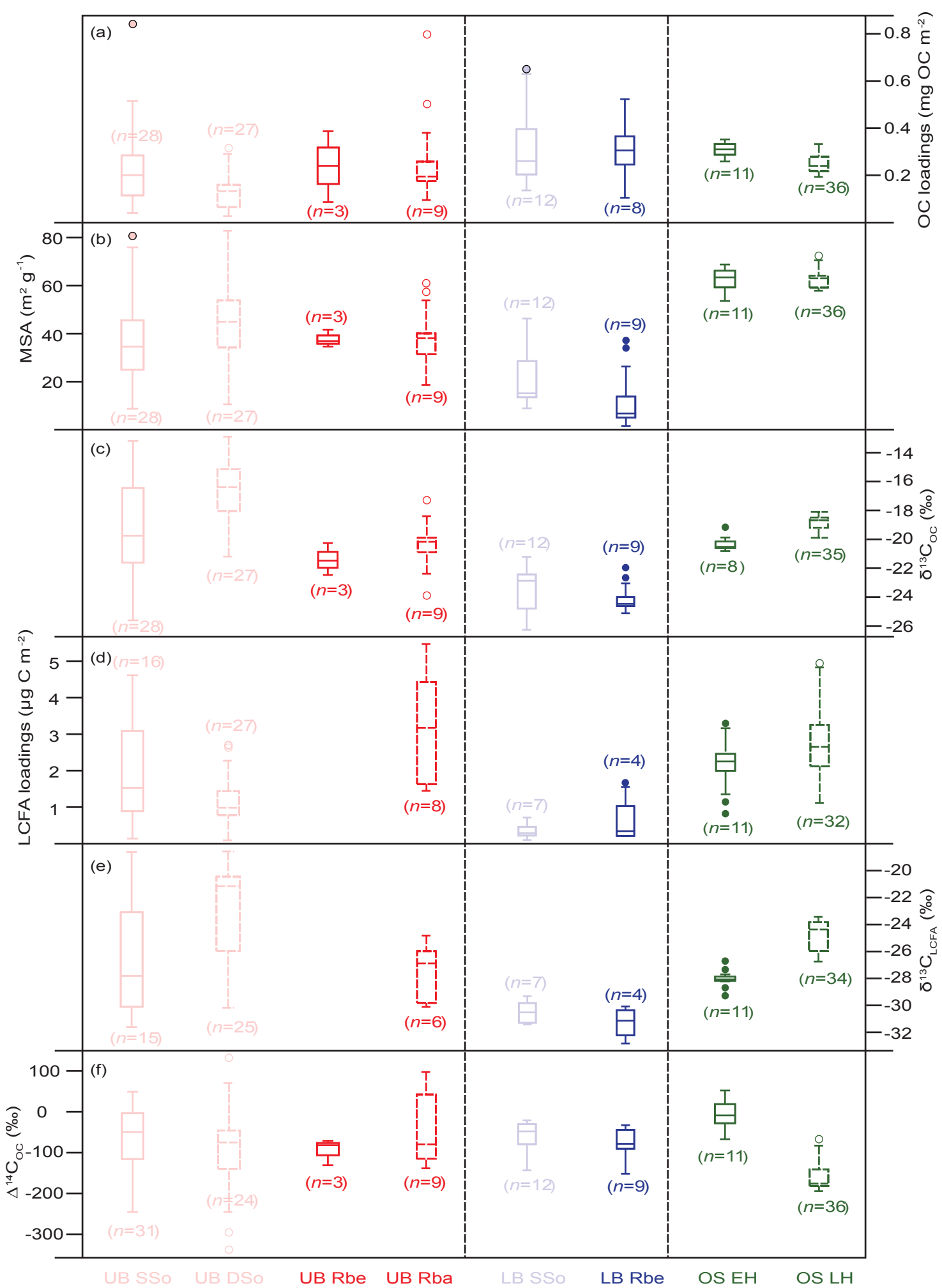

Figure 8. Box-and-whisker summary of the geochemical and sedimentological data for the Godavari River basin and offshore sediments. (a) Organic carbon loadings, (b) mineral surface area (MSA), (c) bulk stable carbon isotope ratio, (d) long-chain fatty acid loadings, (e) mean weighted stable carbon isotope ratio of long-chain $\left(\mathrm{C}_{26-32}\right)$ fatty acid, and (f) bulk radiocarbon signature. The box represents the first $(\mathrm{Q} 1)$ and third quartiles $(\mathrm{Q} 3)$, and the line in the box indicates the median value. The whiskers extend to $1.5 \cdot(\mathrm{Q} 3-\mathrm{Q} 1)$ values, and outliers are shown as points. $\mathrm{SSo}=$ surface soil; $\mathrm{DSo}=$ deep soil; $\mathrm{Rbe}=$ riverbed; Rba = riverbank; $\mathrm{EH}=$ early Holocene; $\mathrm{LH}=$ late Holocene. 
basin, but also the processes (loss and replacement vs. sediment dilution) that influence the nature of OC.

\subsection{Linkages between Godavari drainage basin and marine sedimentary signals}

The Holocene record from core 16A (Figs. 5, 7, 8; Table S2) shows that increasing long-chain plant wax $\delta^{13} \mathrm{C}$ values from the early to late Holocene coincide with other lines of evidence indicating a transition to drier conditions on the Indian and Arabian peninsulas (Ponton et al., 2012; Prasad et al., 2014). Because $C_{4}$ vegetation is adapted to more arid conditions, the marked isotopic change beginning at $\sim 4.5 \mathrm{kyr} \mathrm{BP}$, accompanied by a shift in neodymium isotopic composition towards Deccan bedrock signatures (Tripathy et al., 2011) in detrital phases, has been interpreted to reflect a shift in sediment provenance associated with changes in basin hydrology, resulting in increased sediment flux from the upper Godavari catchment to the adjacent continental margin (Giosan et al, 2017).

In contrast to the river basin sediments and soils, the uniform distribution of grain size and mineral surface area in receiving basin sediments is likely a result of hydrodynamic sorting during fluvial transport and export of sediments to the BoB. Thus, in order to compare and contrast signals emanating from the Godavari drainage basin with those in sediments deposited on the adjacent continental margin, it is important to take into account processes that may induce particle mobilization, transformation, and sorting. Normalization to MSA may provide a means to address this problem, as it eliminates hydrodynamic sorting effects due to GS, particle density, and shape (Freymond et al., 2018). Marked differences between early vs. late Holocene offshore sediments that mimic upper vs. lower-basin signals, respectively, are evident when MSA normalized OC (OC / MSA) is plotted vs. $\delta^{13} \mathrm{COC}_{\mathrm{OC}}$ (Figs. 5a and 8). The mean OC loadings of early $\left(0.33 \pm 0.03 \mathrm{mg} \mathrm{OC} \mathrm{m}^{-2}\right)$ and late Holocene $\left(0.25 \pm 0.04 \mathrm{mg} \mathrm{OC} \mathrm{m}^{-2}\right)$ sediments are similar to mean loading values observed in lower- $\left(0.31 \pm 0.12 \mathrm{mg} \mathrm{OC} \mathrm{m}^{-2}\right)$ and upper-basin $\left(0.24 \pm 0.15 \mathrm{mg} \mathrm{OC} \mathrm{m}^{-2}\right)$ riverbed sediments, respectively. In addition, these values are similar to the OC loadings of soils from the respective source regions in the basin $\left(0.29 \pm 0.14\right.$ and $0.23 \pm 0.17 \mathrm{mg} \mathrm{OC} \mathrm{m}^{-2}$ for lower and upper-basin soils, respectively). The early Holocene part of the record is characterized by relatively high OC loading and lower $\delta^{13} \mathrm{C}_{\mathrm{OC}}$ values that progressively shift towards lower OC loading and relatively higher $\delta^{13} \mathrm{C}_{\mathrm{OC}}$ values during the latter part of Holocene (Fig. 5).

There have only been limited investigations on the longitudinal evolution of $\mathrm{OM}$-mineral interactions during transit through river basins (Freymond et al., 2018). However, evidence suggests that loss and replacement of OM may be substantial within floodplains, estuarine, and deltaic systems (Galy et al., 2008; Keil et al., 1997). Estimates of MSA in marine sediments are complicated by the production and de- position of biogenic carbonate and opal (Hobert and Wetzel, 1989). However, sediment trap data from the central $\mathrm{BoB}$ suggest that modern-day carbonate and opal fluxes to BoB are relatively low $\left(0.03-3.1 \mathrm{~g} \mathrm{~m}^{-2}\right.$ per year; Sarin et al., 1979). In addition, low foraminifera abundances and high sedimentation rates supported by detrital sediment inputs (Giosan et al, 2017), especially during the late Holocene, minimize the effect of carbonate and opal influences on MSA measurements at this location. Consequently, the measured MSA was interpreted as exclusively reflecting fluvially derived lithogenic materials. In this context, we do not find any systematic difference in MSA between early and late Holocene sediments, with OC loadings that plot within the general range that is characteristic of deltaic and deep-sea sediments (Fig. 4; Blair and Aller, 2012).

Bulk OC loading vs. $\delta^{13} \mathrm{C}_{\mathrm{OC}}$ and $\Delta^{14} \mathrm{C}$ show that at higher loading, $\mathrm{OC}$ is relatively ${ }^{13} \mathrm{C}$-depleted and enriched in ${ }^{14} \mathrm{C}$, whereas the reverse is the case at lower loading (Fig. 5). Direct comparisons of bulk OC loadings between marine sediment core and river basin soils and sediments are not straightforward, as the likely addition of marine carbon to offshore sediments introduces a layer of complexity to such comparison. In contrast, LCFAs derive exclusively from higher terrestrial plants, enabling more direct comparison of loadings between riverine and offshore sediment. Adopting the biomarker loadings concept described by Freymond et al. (2018), we find elevated LCFA loading in the upper basin compared to the lower basin (Figs. 6a and 8), and a similar range of LCFA loadings in sediments deposited during the early and late Holocene to that observed in soils and sediments of the lower and upper basin, respectively. This suggests that the loading signatures in early vs. late Holocene are likely a consequence of the changes in sediment provenance previously inferred from neodymium isotopic data (Giosan et al., 2017).

The progressive increase in stable carbon isotopic values of bulk $\left(\delta^{13} \mathrm{C}_{\mathrm{OC}}\right)$ and long-chain fatty acids $\left(\delta^{13} \mathrm{C}_{\mathrm{LCFA}}\right)$ from the marine sediment core towards the late Holocene has been interpreted as an enhanced supply of $\mathrm{C}_{4}$-derived $\mathrm{OC}$ sourced from the Deccan Plateau during the late Holocene triggered by changes in Indian monsoon strength and/or location (Gadgil et al., 2003; Sinha et al., 2011; Webster et al., 1998). Our new results from within the drainage basin lend support for a significant reorganization in sediment and OC provenance from lower to upper-basin sources.

The decay-corrected ${ }^{14} \mathrm{C}$ values of the sediment core are bracketed by the range of values of surface and deep soils from the upper and lower basin (Figs. 7 and 8). This suggests that the core consists of a mixture of pre-aged carbon sourced from deep soils and fresh carbon from plant litters and possibly freshwater algae. It should, however, be noted that soil samples, including deeper soil layers, have likely been impacted by "bomb ${ }^{14} \mathrm{C}$ " (see Trumbore et al., 1989; van der Voort et al., 2017). There is a general decrease in the $\Delta$ values towards the late Holocene, and the ranges of $\Delta$ values of 
the late Holocene sediment are only observed in the deeper sections of upper-basin soils (Fig. S2).

Taken together, these sedimentological and geochemical results suggest that export of $\mathrm{OC}$-poor $\mathrm{C}_{4}$-dominated and smectite-rich mineral soils intensified in the late Holocene, with the observed shift ca. $4.5 \mathrm{kyr}$ BP reflecting a shift in sediment provenance from lower basin to upper basin. Furthermore, much of these upper-basin sediments were likely derived from deeper, older, more degraded Deccan soils. This apparent shift in the loci and nature of soil mobilization is also accompanied by a 3-fold increase in sediment flux (Pradhan et al., 2014), implying extensive soil loss from the upper catchment (e.g. Van Oost et al., 2012). This loss may have stemmed from both natural (aridification and associated reduction in vegetation cover) and anthropogenic (agriculture and irrigation) causes, the latter potentially being triggered by changes in regional climate.

For the period spanning the late Holocene, perturbations within river basins due to natural climate variability have become intertwined with those stemming from human activity. This is particularly so for subtropical river basins of central Asia, where the influence of anthropogenic activity on the landscape and watersheds extends back several millennia (e.g. Van Oost et al., 2012). Within the past 2 centuries, humans have imparted particularly dramatic changes on drainage basins both in terms of land use (e.g. deforestation, agricultural practices) and modification of water networks through dam construction and other major perturbations (Syvitski et al., 2005).

Both the landscape and hydrological characteristics of the Godavari basin have been dramatically altered over the past century. For example, in the past few decades, there has been a 10-fold decrease in OC flux from the Godavari to the BoB due to reduced monsoon rainfall and to dam constructions (Gupta et al., 1997; Pradhan et al., 2014). However, the late Holocene section generally mimics modern-day upper-basin signatures in high fidelity, suggesting that the perturbations of the modern Godavari had little impact on sediment and OC mobilization.

The general agreement between signals emanating from the river basin and those recorded in the sedimentary archive provides valuable insights into understanding the major mechanisms of sediment and OC mobilization, the dynamics and interactions of organic matter and sedimentary minerals during fluvial transport, and their impact on the provenance and nature of signals exported from the drainage basin. Furthermore, such studies that seek to reconcile drainage and receiving basin characteristics, as well as climate and anthropogenic influences on these connections, are necessary to determine the factor(s) controlling the nature and fate of OC preserved in sedimentary archives.

\section{Conclusions}

In this study, we sought to reconcile previously observed geochemical variations in the Holocene sediments deposited in the BoB offshore of the Godavari River with those observed in soils and sediments within the modern drainage basin.

Distinct contrasts were observed in the abundance and characteristics of OM and mineral components of soils and fluvial sediments in the upper and the lower basin. The former (upper basin) are characterized by $\mathrm{C}_{4}$-dominated $\mathrm{OM}$ associated with high-surface-area Deccan-sourced mineral phases, whereas those of the lower basin contain higher proportions of $\mathrm{C}_{3}$-plant-derived $\mathrm{OM}$.

The strong links between OM characteristics and sediment mineralogy (GS, MSA) suggest that OM-mineral interactions play an important role in OC stabilization throughout the Godavari source-to-sink system, from mobilization to export.

Comparison of bulk and molecular-level characteristics of drainage basin and marine sediment core show that a marked mid-Holocene transition is consistent with a change in sediment provenance towards a greater contribution of Deccansourced material in the upper basin, although extensive anthropogenic perturbation of the modern Godavari system limits the effective transmission of the upper signal to the deltaic region and offshore. However, given the limited accommodation space that restricts upstream trapping and promotes rapid export, anthropogenic influences on the flux and nature of OC exported from the Godavari basin may be subject to marked future changes.

Our findings suggest that reconstruction of past continental conditions based on terrestrial biomarker proxy records in marine sediments need to consider potential shifts in signal provenance as a consequence of both natural and anthropogenic forcing.

Data availability. All underlying research data associated with this study are available in the Supplement.

Supplement. The supplement related to this article is available online at: https://doi.org/10.5194/bg-15-3357-2018-supplement.

Competing interests. The authors declare that they have no conflict of interest.

Acknowledgements. We thank the associate editor Markus Kienast and two anonymous reviewers for their comments. This project was supported by the Swiss National Science Foundations ("CAPS LOCK" grant no. 200021-140850 and "CAPS-LOCK2" grant no. 200021-163162). Francien Peterse received funding from NWO-Veni grant (grant no. 863.13.016). Liviu Giosan thanks colleagues and crew from the NGHP-01 expedition for intellectual 
interactions leading to pursuing work on fluvial-continental margin systems of Peninsular India and to grants from the National Science Foundation (OCE-0841736) and Woods Hole Oceanographic Institution. We also wish to thank Daniel Montluçon for laboratory assistance, and we acknowledge the logistical support of Prasanta Sanyal and Chris Martes with sampling. Further thanks to Michael Strupler for help with grain size measurements. This paper benefitted from discussions with Chantal Freymond.

Edited by: Markus Kienast

Reviewed by: two anonymous referees

\section{References}

Arnarson, T. and Keil, R.: Changes in organic matter-mineral interactions for marine sediments with varying oxygen exposure times, Geochim. Cosmochim. Ac., 71, 3545-3556, https://doi.org/10.1016/j.gca.2007.04.027, 2007.

Asouti, E. and Fuller, D.: Trees and Woodlands in South India: Archaeological Perspectives, Left Coast Press, Walnut Creek, California, 2008.

Aufdenkampe, A. K., Mayorga, E., Raymond, P. A., Melack, J. M., Doney, S. C., Alin, S. R., Aalto, R. E., and Yoo, K.: Riverine coupling of biogeochemical cycles between land, oceans, and atmosphere, Front. Ecol. Environ., 9, 53-60, https://doi.org/10.1890/100014, 2011.

Balakrishna, K. and Probst, J.: Organic carbon transport and $\mathrm{C} / \mathrm{N}$ ratio variations in a large tropical river: Godavari as a case study, India, Biogeochemistry, 73, 457-473, https://doi.org/10.1007/s10533-004-0879-2, 2005.

Bao, R., McIntyre, C., Zhao, M., Zhu, C., Kao, S.-J., and Eglinton, T.: Widespread dispersal and aging of organic carbon in shallow marginal seas, Geology, 44, 791-794, https://doi.org/10.1130/G37948.1, 2016.

Bendle, J. A., Weijers, J. W. H., Maslin, M. A., Sinninghe-Damsté, J. S., Schouten, S., Hopmans, E. C., Boot, C. S., and Pancost, R. D.: Major changes in glacial and Holocene terrestrial temperatures and sources of organic carbon recorded in the Amazon fan by tetraether lipids, Geochem. Geophy. Geosy., 11, Q12007, https://doi.org/10.1029/2010GC003308, 2010.

Bergmann, J. and Kleeberg, R.: Rietveld analysis of disordered layer silicates, Material Science Forum, 278-281, 300-305, https://doi.org/10.4028/www.scientific.net/MSF.278281.300, 1998.

Berner, R.: Burial of organic carbon and pyrite sulfur in the modern ocean: its geochemical and environmental significance, Am. J. Sci., 282, 451-473, https://doi.org/10.2475/ajs.282.4.451, 1989.

Berner, R.: The long-term carbon cycle, fossil fuels and atmospheric composition, Nature, 426, 323-326, https://doi.org/10.1038/nature02131, 2003.

Bhattacharyya, T., Pal, D. K., Mandal, C., Chandran, P., Ray, S. K., Sarkar, D., Velmourougane, K., Srivastava, R., Tiwary, P., Nagar, A. P., and Nimkhedkar, S. S.: Soils of India: historical perspective, classification and recent advances, Curr. Sci., 104, 13081323, 2013.

Biksham, G. and Subramanian, V.: Sediment transport of the Godavari River Basin and its controlling factors, J. Hydrol., 101, 275-290, https://doi.org/10.1016/0022-1694(88)90040-6, 1988.
Bish, D. and Plötze, M.: X-ray powder diffraction with emphasis on qualitative and quantitative analysis in industrial mineralogy, in: Advances in the characterization of industrial minerals, edited by: Christidis, G., EMU and Mineralogical Society, London, 3676, 2011.

Blair, N. and Aller, R.: The Fate of Terrestrial Organic Carbon in the Marine Environment, Ann. Rev. Mar. Sci., 4, 401-423, https://doi.org/10.1146/annurev-marine-120709-142717, 2012.

Cole, J. J., Prairie, Y. T., Caraco, N. F., McDowell, W. H., Tranvik, L. J., Striegel, R. G., Duarte, C. M., Kortelainen, P., Downing, J. A., Middleburg, J. J., and Melack, J.: Plumbing the global carbon cycle: Integrating inland waters into the terrestrial carbon budget, Ecosystems, 10, 171-184, https://doi.org/10.1007/s10021006-9013-8, 2007.

Coleman, J.: Brahmaputra River: Channel processes and sedimentation, Sediment. Geol., 3, 129-139, https://doi.org/10.1016/00370738(69)90010-4, 1969.

Collett, T., Boswell, R., Cochran, J., Kumar, P., Lall, M., Mazumdar, A., Raman, M., Ramprasad, T., Riedel, M., Sain, K., Sathe, A., Vishwanath, K., and Party, N. E.: Geologic implications of gas hydrates in the offshore of India: Results of the National Gas Hydrate Program Expedition 01, Mar. Pet. Geol, 58, 3-28, https://doi.org/10.1016/j.marpetgeo.2014.07.021, 2014.

Craig, H.: The geochemistry of the stable carbon isotopes, Geochim. Cosmochim. Ac., 3, 53-92, https://doi.org/10.1016/0016-7037(53)90001-5, 1953.

Cui, M., Wang, Z., Nageswara Rao, K., Sangode, S. J., Saito, Y., Chen, T., Kulkarni, Y. R., Naga Kumar, K. C. V., and Demudu, G.: A mid- to late-Holocene record of vegetation decline and erosion triggered by monsoon weakening and human adaptations in the south-east Indian Peninsula, The Holocene, 27, 1976-1987, https://doi.org/10.1177/0959683617715694, 2017.

Degens, E., Kempe, S., and Richey, J.: Summary: biogeochemistry of major world rivers, in: Biogeochemistry of major world rivers, edited by: Degens, E., Kempe, S., and Richey, J., Wiley, Chichester, 323-348, 1991

Ertel, J. and Hedges, J.: Sources of sedimentary humic substances: vascular plant debris, Geochim. Cosmochim. Ac, 49, 2097-2107, https://doi.org/10.1016/0016-7037(85)90067-5, 1985.

Freymond, C. V., Kündig, N., Stark, C., Peterse, F., Buggle, B., Lupker, M., Plötze, M., Blattmann, T. M., Filip, F., Giosan, L., and Eglinton, T.: Evolution of biomolecular loadings along a major river system, Geochim. Cosmochim. Ac., 223, 389-404, https://doi.org/10.1016/j.gca.2017.12.010, 2018.

Gadgil, S.: The Indian monsoon and its variability, Ann. Rev. Earth Planet. Sci., 31, 429-467, https://doi.org/10.1146/annurev.earth.31.100901.141251, 2003.

Galy, V. and Eglinton, T.: Protracted storage of biospheric carbon in the Ganges-Brahmaputra basin, Nat. Geosci., 4, 843-847, https://doi.org/10.1038/ngeo1293, 2011.

Galy, V., France-Lanord, C., and Lartiges, B.: Loading and fate of particulate organic carbon from the Himalaya to the GangaBrahmaputra delta, Geochim. Cosmochim. Ac., 72, 1767-1787, https://doi.org/10.1016/j.gca.2008.01.027, 2008.

Giosan, L., Ponton, C., Usman, M., Blusztajn, J., Fuller, D. Q., Galy, V., Haghipour, N., Johnson, J. E., McIntyre, C., Wacker, L., and Eglinton, T. I.: Short communication: Massive erosion in monsoonal central India linked to late Holocene 
land cover degradation, Earth Surf. Dynam., 5, 781-789, https://doi.org/10.5194/esurf-5-781-2017, 2017.

Goni, M., Yunker, M., Macdonald, R., and Eglinton, T.: The supply and preservation of ancient and modern components of organic carbon in the Canadian Beaufort Shelf of the Arctic Ocean, Mar. Chem., 93, 53-73, https://doi.org/10.1016/j.marchem.2004.08.001, 2005.

Gordon, E. and Goni, M.: Controls on the distribution and accumulation of terrigenous organic matter in sediments from the Mississippi and Atchafalaya river margin, Mar. Chem., 92, 331-352, https://doi.org/10.1016/j.marchem.2004.06.035, 2004.

Gunnell, Y., Anupama, K., and Sultan, B.: Response of the South Indian runoff-harvesting civilization to northeast monsoon rainfall variability during the last 2000 years: instrumental records and indirect evidence, The Holocene, 17, 207-215, https://doi.org/10.1177/0959683607075835, 2007.

Gupta, L., Subramanian, V., and Ittekkot, V.: Biogeochemistry of particulate organic matter transported by the Godavari River, India, Biogeochemistry, 38, 103-128, https://doi.org/10.1023/A:1005732519216, 1997.

Hedges, J.: Global biogeochemical cycles: progress and problems, Mar. Chem., 39, 67-93, https://doi.org/10.1016/03044203(92)90096-S, 1992.

Hedges, J., Clark, W., Quay, P., Richey, J., Devol, A., and Santos, U.: Composition and fluxes of particulate organic material in the Amazon river, Limnol. Oceanogr., 31, 717-738, https://doi.org/10.4319/lo.1986.31.4.0717, 1986.

Hilton, R., Galy, A., Hovius, N., Chen, M.-C., Horng, M.-J., and Chen, H.: Tropical-cyclone-driven erosion of the terrestrial biosphere from mountains, Nat. Geosci., 1, 759-762, https://doi.org/10.1038/ngeo333, 2008.

Hobert, L. and Wetzel, A.: On the relationship between silica and carbonate diagenesis in dep-sea sediments, Int. J. Earth Sci., 78, 765-778, https://doi.org/10.1007/BF01829321, 1989.

Kale, V.: Fluvial geomorphology of Indian rivers: an overview, Prog. Phys. Geogr., 26, 400-433, https://doi.org/10.1191/0309133302pp343ra, 2002.

Keil, R., Mayer, L., Quay, P., Richey, J., and Hedges, J.: Loss of organic matter from riverine particles in deltas, Geochim. Cosmochim. Ac., 61, 1507-1511, https://doi.org/10.1016/S00167037(97)00044-6, 1997.

Kessarkar, P. M., Rao, V. P., Ahmad, S. M., and Babu, G. A.: Clay minerals and $\mathrm{Sr}-\mathrm{Nd}$ isotopes of the sediments along the western margin of India and their implication for sediment provenance, Mar. Geol., 202, 55-69, https://doi.org/10.1016/S00253227(03)00240-8, 2003.

Komada, T., Anderson, M., and Dorfmeier, C.: Carbonate removal from coastal sediments for the determination of organic carbon and its isotopic signatures, $\delta 13 \mathrm{C}$ and $\Delta 14 \mathrm{C}$ : comparison of fumigation and direct acidification by hydrochloric acid, Limnol. Oceanogr.-Meth., 6, 254-262, https://doi.org/10.4319/lom.2008.6.254, 2008.

Kulkarni, Y. R., Sangode, S. J., Blomendal, J., Meshram, D. C., and Suresh, N.: Mineral Magnetic Characterization of the Godavari River and Western Bay of Bengal: Implications to Source to Sink Relations, J. Geol. Soc. India, 85, 71-78, 2015.

Leithold, E., Blair, N., and Perkey, D.: Geomorphologic controls on the age of particulate organic carbon from small mountain- ous and upland rivers, Global Biogeochem. Cy., 20, GB3022, https://doi.org/10.1029/2005GB002677, 2006.

Ludwig, W., Probst, J., and Kempe, S.: Predicting the oceanic input of organic carbon by continental erosion, Global Biogeochem. Cy., 10, 23-41, https://doi.org/10.1029/95GB02925, 1996.

Manmohan, M., Rao, M., Kamaraju, A., and Yalamarty, S.: Origin and occurence of Lower Cretaceous high gamma-high resistivity shale- a key stratigraphic sequence for hydrocarbon exploration in the Krishna-Godavari basin, A.P., J. Geol. Soc. India, 62, 271289, 2003.

Marin-Spiotta, E., Gruley, K. E., Crawford, J., Atkinson, E. E., Miesel, J. R., Greene, S., Crardona-Correa, C., and Spencer, R.: Paradigm shifts in soil organic matter research affect interpretations of aquatic carbon cycling: transcending disciplinary and ecosystem boundaries, Biogeochemistry, 117, 279-297, https://doi.org/10.1007/s10533-013-9949-7, 2014.

Marwick, T., Tamooh, F., Teodoru, C., Borges, V., Darchambeau, F., and Bouillon, S.: The age of river-transported carbon: A global perspective, Global Biogeochem. Cy., 29, 122-137, https://doi.org/10.1002/2014GB004911, 2015.

Mayer, L.: Relationships between mineral surfaces and organic carbon concentrations in soils and sediments, Chem. Geol., 114, 347-363, https://doi.org/10.1016/0009-2541(94)90063-9, 1994a.

Mayer, L.: Surface area control of organic carbon accumulation in continental shelf sediments, Geochim. Cosmochim. Ac., 58, 1271-1284, https://doi.org/10.1016/0016-7037(94)90381-6, $1994 b$.

McIntyre, C., Wacker, L., Haghipour, N., Blattmann, T., Fahrni, S., Usman, M., Eglinton, T., and Synal, H.: Online 13C and 14C gas measurement by EA-IRMS-AMS at ETH Zuürich, Radiocarbon, 59, 893-903, https://doi.org/10.1017/RDC.2016.68, 2016.

Meybeck, M.: Carbon, nitrogen, and phosphorus transport by world rivers, Am. J. Sci., 282, 401-450, https://doi.org/10.2475/ajs.282.4.401, 1982.

Murthy, K., Subramanam, A., Lakshminarayana, S., Chandrasekhar, D., and Rao, T.: Some geodynamics aspect of the Krishna-Godavari basin, east coast of India, Cont. Shelf Res., 15, 779-788, https://doi.org/10.1016/0278-4343(94)00044-N, 1995.

Pessenda, L., Gouveia, S., Aravena, R., Gomes, B., Boulet, R., and Ribeiro, S.: 14C Dating and stable carbon isotopes of soil organic matter in forst-savanna boundary areas in the southern Brazilian Amazon region, Radiocarbon, 40, 1013-1022, https://doi.org/10.1017/S0033822200018981, 1997.

Philips, S. C., Johnson, J., Underwood, M. B., Guo, J., Giosan, L., and Rose, K.: Long-timescale variation in bulk and clay mineral composition of Indian continental margin sediment in the Bay of Bengal, Arabian Sea, and Andaman Sea, Mar. Pet. Geol., 58, 117-138, https://doi.org/10.1016/j.marpetgeo.2014.06.018, 2014.

Ponton, C., Giosan, L., Eglinton, T., Fuller, D., Johnson, J., Kumar, P., and Collett, T.: Holocene aridification of India, Geophys. Res. Lett., 39, L03704, https://doi.org/10.1029/2011GL050722, 2012.

Pradhan, U., Wu, Y., Shirodkar, P., Zhang, J., and Zhang, G.: Multiproxy evidence for compositional change of organic matter in the largest tropical (peninsular) river basin of India, J. Hydrol., 519, 999-10009, https://doi.org/10.1016/j.jhydrol.2014.08.018, 2014.

Prasad, S., Anoop, A., Riedel, N., Srakar, S., Menzel, P., Basavaiah, N., Krishnan, R., Fuller, D., Plessen, B., Gaye, 
B., Röhl, U., Wilkes, H., Sachse, D., Sawant, R., Wiesner, M., and Stebich, M.: Prolonged monsoon droughts and links to Indo-Pacific warm pool: A Holocene record from Lonar Lake, central India, Earth Planet. Sci. Lett., 391, 171-182, https://doi.org/10.1016/j.epsl.2014.01.043, 2014.

Rao, K., Sadakata, N., Malini, B., and Takayasu, K.: Sedimentation processes and asymmetric development of the Godavari delta, Sepm. Spec. P., 89, 433-449, https://doi.org/10.2110/pec.05.83.0435, 2005.

Sarin, M., Borole, D., and Krishnaswami, S.: Geochemistry and geochronology of sediments from the Bay of Bengal and the equatorial Indian Ocean, P. Natl. Acad. Sci. USA, 88, 131-154, 1979.

Schefuss, E., Kuhlmann, H., Mollenhauer, G., Prange, M., and Pätzold, J.: Forcing of wet phases in southeast Africa over the past 17,000 years, Nature, 480, 509-512, https://doi.org/10.1038/nature10685, 2011.

Schefuss, E., Eglinton, T., Spencer-Jones, C., Rullkötter, J., De Pol-Hols, R., Talbot, H., Grootes, P., and Schneider, R.: Hydrologic control of carbon cycling and aged carbon discharge in the Congo River basin, Nat. Geosci., 9, 687-690, https://doi.org/10.1038/ngeo2778, 2016.

Schlünz, B. and Schneider, R.: Transport of terrestrial organic carbon to the oceans by rivers: re-estimating flux-and burial rates, Int. J. Earth Sci., 88, 599-606, https://doi.org/10.1007/s005310050290, 2000.

Shen, C., Yi, W., Sun, Y., Xing, C., Yang, Y., Yuan, C., Li, Z., Peng, S., An, Z., and Liu, T.: Distribution of $14 \mathrm{C}$ and $13 \mathrm{C}$ in forest soils of the Dinghushan biosphere reserve, Radiocarbon, 43, 671-678, https://doi.org/10.1017/S0033822200041321, 2001.

Shrivastava, J. P. and Pattanayak, S. K.: Basalts of the Eastern Deccan Volcanic Province, India, Gondwana Res., 5, 649-665, https://doi.org/10.1016/S1342-937X(05)70636-5, 2002.

Silviera, D.: India Book, Classic Publishers, Goa, India, 1993.

Sinha, A., Stott, L., Berkelhammer, M., Cheng, H., Edwards, R. L., Buckley, B., Aldenderfer, M., and Mudelsee, M.: A global context for megadroughts in monsoon Asia during the past millenium, Quaternary Sci. Rev.,30, 47-62, https://doi.org/10.1016/j.quascirev.2010.10.005, 2011.

Spencer, R., Hernes, P., Aufdenkampe, A., Baker, A., Gulliver, P., Stubbins, A., Aiken, G., Dyda, R., Butler, K., Mwamba, V., Mangangu, A., and Wabakanghanzi, S.: An initial investigation into the organic matter biogeochemistry of the Congo River, Geochim. Cosmochim. Ac., 84, 614-627, https://doi.org/10.1016/j.gca.2012.01.013, 2012.

Sridhar, P. N., Ali, M. M., Vethamony, P., Babu, M. T., Ramana, I. V., and Jayakumar, S.: Seasonal Occurrence of Unique Sediment Plume in the Bay of Bengal, Eos Trans. AGU, 89, 22-23, https://doi.org/10.1029/2008EO030002, 2008.

Srivastava, P., Parkash, B., and Pal, D. K.: Clay Minerals in Soils as Evidence of Holocene Climatic Change, Central IndoGangetic Plains, North-Central India, Quatern. Res., 50, 230239, https://doi.org/10.1006/qres.1998.1994, 1998.

Stuiver, M. and Polach, H.: Reporting of C-14 data - Discussion, Radiocarbon, 19, 355-363, https://doi.org/10.1017/S0033822200003672, 1977.

Subramanian, V.: Geomorphology of the Deccan volcanic province, in: Deccan Volcanism and Related Basalt Provinces in Other
Parts of the World, edited by: Rao, S., Hindustan Publisher, New Delhi, India, p. 467, 1981.

Syvitski, J. P. M., Vörösmarty, C. J., Kettner, A. J., and Green, P.: Impacts of humans on the flux of terrestrial sediment to the global coastal ocean, Science, 308, 376-380, https://doi.org/10.1126/science.1109454, 2005.

Tao, S., Eglinton, T., Montlucon, D., McIntyre, C., and Zhang, M.: Pre-aged soil organic carbon as a major component of the Yellow River suspended load: Regional significance and global relevance, Earth Planet. Sci. Lett., 414, 77-86, https://doi.org/10.1016/j.epsl.2015.01.004, 2015.

Tripathy, G., Singh, S., Bhushan, R., and Ramaswamy, V.: Sr-Nd isotope composition of the Bay of Bengal Sediments: Impact of Climate on Erosion in the Himalaya, Geochem. J., 45, 175-186, https://doi.org/10.2343/geochemj.1.0112, 2011.

Trumbore, S., Vogel, J., and Southon, J.: AMS 14C measurements of fractionated soil organic matter: an approach to deciphering the soil carbon cycle, Radiocarbon, 31, 644-654, https://doi.org/10.1017/S0033822200012248, 1989.

van der Voort, T. S., Zell, C. I., Hagedorn, F., Feng, X., McIntyre, C. P., Haghipour, N., Graf Pannatier, E., and Eglinton, T. I.: Diverse Soil Carbon Dynamics Expressed at the Molecular Level, Geophys. Res. Lett., 44, 11,840-850, https://doi.org/10.1002/2017GL076188, 2017.

Van Oost, K., Verstraeten, G., Doetterl, S., Notebaert, B., Wiaux, F., Broothaerts, N., and Six, J.: Legacy of humaninduced $\mathrm{C}$ erosion and burial on soil-atmosphere C exchange, P. Natl. Acad. Sci. USA, 109, 19492-19497, https://doi.org/10.1073/pnas.1211162109, 2012.

Wacker, L., Bonani, G., Friedrich, M., Hajdas, I., Kromer, B., Němec, M., Ruff, M., Synal, H.-A., and Vockenhuber, C.: MICADAS: Routine and High-Precision Radiocarbon Dating, Radiocarbon, 52, 252-262, https://doi.org/10.1017/S0033822200045288, 2010.

Wakeham, S., Canuel, E., Lerberg, E., Mason, P., Sampere, T., and Bianchi, T.: Partitioning of organic matter in continental margin sediments among density fractions, Mar. Chem., 115, 211-225, https://doi.org/10.1016/j.marchem.2009.08.005, 2009.

Wang, X., Cammeraat, E., Cerli, C., and Kalbitz, K.: Soil aggregation and the stabilization of organic carbon as affected by ersosion and deposition, Soil Biol. Biochem., 72, 55-65, https://doi.org/10.1016/j.soilbio.2014.01.018, 2014.

Webster, P. J., Magana, V. O., Palmer, T. N., Shukla, J., Tomas, R. A., Yanai, M., and Yasunari, T.: Monsoon: processes, predictability, and the prospects for prediction, J. Geophys. Res., 103, 14451-14510, https://doi.org/10.1029/97JC02719, 1998.

Weijers, J. W. H., Schefuss, E., Schouten, S., and SinningheDamsté, J. S.: Coupled thermal and hydrological evolution of tropical Africa over the last deglaciation, Science, 315, 17011704, https://doi.org/10.1126/science.1138131, 2007.

Wu, Y., Dittmar, T., Ludwichowski, K., Kattner, G., Zhang, J., Zhu, Z., and Kock, B.: Tracing suspended organic nitrogen from the Yangtze River catchment inot the East China Sea, Mar. Chem., 107, 367-377, https://doi.org/10.1016/j.marchem.2007.01.022, 2007.

Zhang, G., Germaine, J., Martin, R., and Whittle, J.: A simple sample-mounting method for random powder X-ray diffraction, Clay Clay Miner., 51, 218-225, https://doi.org/10.1346/CCMN.2003.0510212, 2003. 
Zorzi, C., Goni, M., Anupama, K., Prasad, S., Hanquiez, V., Johnson, J., and Giosan, L.: Indian monsoon variations during three contrasting climatic periods: The Holocene, Heinrich Stadial 2 and the last interglacial-glacial transition, Quaternary Sci. Rev., 125, 50-60, https://doi.org/10.1016/j.quascirev.2015.06.009, 2015. 